\title{
Graptemys geographica (LeSueur 1817) - Northern Map Turtle, Common Map Turtle
}

\author{
Richard C. Vogt ${ }^{1}$, Grégory Bulté ${ }^{2}$, AND John B. IVERSON ${ }^{3}$ \\ ${ }^{1}$ Coordinação de Biodiversidade, Instituto Nacional de Pesquisas da Amazônia (INPA), \\ Ave. André Araujo 2936, Aleixo, Manaus,69.067-375 Amazonas, Brazil [vogt@inpa.gov.br]; \\ ${ }^{2}$ Department of Biology, Carleton University, Ottawa, Ontario, K1S 5B6 Canada [gregory.bulte@carleton.ca]; \\ ${ }^{3}$ Department of Biology, Earlham College, Richmond, Indiana 47374 USA [johni@earlham.edu]
}

Summary. - The Northern Map Turtle, Graptemys geographica (Family Emydidae), is a mediumsized sexually dimorphic freshwater turtle species (female carapace length to $292 \mathrm{~mm}$, males to 160 $\mathrm{mm}$ ) and the sister taxon to all other map turtle species. It is often common in rivers and lakes within its North American range. The turtles make extensive movements within their habitats for nesting, basking, and feeding. Mating occurs in fall and spring; hibernation lasts from October to mid-April in northern regions, and most hatchlings overwinter in the nest. Northern Map Turtles are primarily carnivorous, feeding predominately on snails, bivalves (including invasive dreisennid mussels), and aquatic insect larvae. Two to three clutches of 6 to 20 eggs are laid each year between late May and mid-July. Because males mature after about 4 years and females require about 10 years, adult sex ratios are often skewed towards males. Sex ratios are also influenced by nest temperatures, with warmer nests producing females and cool nests producing males. Direct and indirect human activities, including fisheries by-catch mortality, appear to be responsible for some population declines of this species in some regions, but G. geographica is not at this time considered Threatened.

Distribution. - Canada, USA. Southwestern Quebec and southeastern Ontario to central Alabama, northern Louisiana, west to central Minnesota and eastern Kansas and Arkansas, with scattered isolated populations in the northeastern USA in Vermont, New York, New Jersey, and Pennsylvania.

Synonymy. - Testudo geographica LeSueur 1817, Emys geographica, Terrapene geographica, Graptemys geographica,Clemmys geographica,Malacoclemmys geographica,Malaclemys geographica, Malaclemys geographicus, Malaclemmys geographicus, Graptemys geographicus, Emys lesueurii Gray 1830, Graptemys lesueurii, Malacoclemmys lesueurii, Malaclemys lesueurii, Malaclemys lesueurii lesueurii, Emys megacephala Holbrook 1836, Emys macrocephala Agassiz 1857 (nomen novum).

SubSPECIES. - None recognized.

STATUS. - IUCN 2017 Red List: Least Concern (LC, assessed 2010); CITES: Appendix III (USA) as Graptemys spp.; US ESA: Special Concern; Canada Species at Risk Act: Special Concern.

Taxonomy. - Graptemys geographica has had a stable taxonomic history since its original description by LeSueur (1817) as Testudo geographica, despite its redescription as Emys lesueurii by Gray (1830), Emys megacephala by Holbrook (1836), and Emys macrocephala by Agassiz (1857), and its placement in seven different genera over the years. Graptemys geographica is the sister taxon to all other Graptemys (Lamb et al. 1994; Lamb and Osentoski 1997; Stephens and Wiens 2003, 2004; Wiens et al. 2010; Thomson et al. 2018). Lamb et al. (1994) estimated that the geographica lineage diverged from other Graptemys 6 to 8 million years ago, while Thomson et al. (2018) estimated the divergence to fall between 3.97 and 8.91 million years ago. Thomson et al. (2018) reported no apparent genetic structuring across the species' distribution.

Based on phenotypes and hatchlings from known females, Vogt (1978) reported hybridization with Graptemys pseudogeographica and Graptemys ouachitensis in the Mississippi River at Stoddard, Wisconsin. The G. pseudogeographica $\mathrm{x}$ geographica female, collected while nesting, produced viable eggs while the only G.ouachitensis $\mathrm{x}$ geographica female, collected while nesting, produced nonviable eggs both in the wild and in the laboratory for 6 years (Vogt 1978, 1993). Hybridization between $G$. geographica and G. pseudogeographica was recently confirmed with molecular markers (Freedberg and Myers 2012; Mitchell et al. 2016). In Reelfoot Lake, Tennessee, where only G. pseudogeographica occurs, Freedberg and Myers (2012) found individuals possessing both nuclear and mitochondrial alleles specific to G. geographica, suggesting that hybridization took place before the formation of Reelfoot Lake in the early 1800s; however, mitochondria carry ancient particles (nuncs) and may have nothing to do with hybridization (U. Fritz, pers. comm. to Vogt). In the 


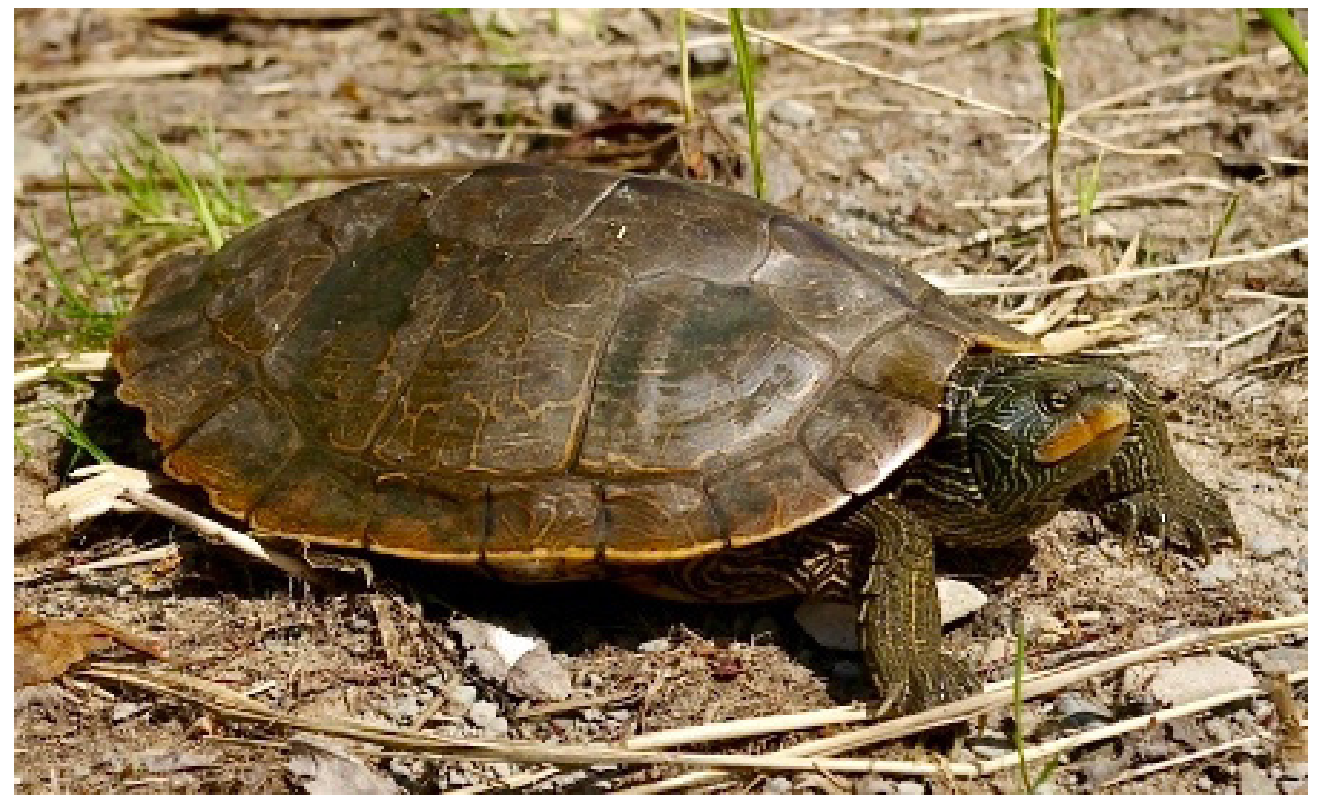

Figure 1. Graptemys geographica female, Quebec, Canada. Photo by M. Ouellette.

Mississippi River, Minnesota, where the two species cooccur, Mitchell et al. (2016) found nuclear alleles specific to G. pseudogeographica in G. geographica, but did not find any interspecific introgression of mitochondrial alleles.

Pleistocene fossil remains assigned to G. geographica have been found in Virginia (Fay 1988), Tennessee (Guilday et al.1978), Texas (Stovall and McAnulty 1950; Slaughter et al. 1962; Holman 1969), and Kansas (Holman 1972; Hibbard

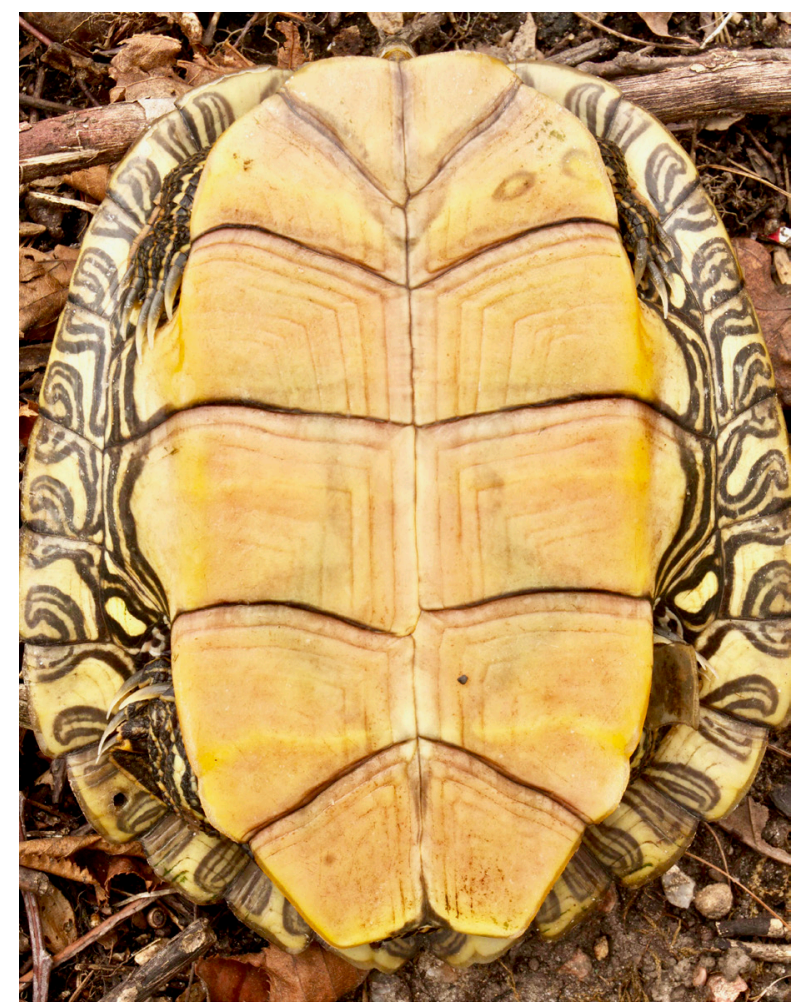

Figure 2. Graptemys geographica female, Lake Opinicon, Ontario, Canada. Photo by G. Bulté. et al.1978). Archeological remains have been described from Iowa (Jenkins and Semken 1972) and Michigan (Adler 1968). The fossil record for Graptemys, including G. geographica, was recently reviewed by Lindeman (2013).

Description. - Graptemys geographica is a mediumsized turtle of rivers and lakes. Sexual dimorphism is pronounced; adult females are 170-292 mm (record 292 mm; Bulté, unpubl. data) and adult males 100-160 mm (Vogt 1981a) in carapace length (CL). Live weight of adult females from the Misssissippi River in Wisconsin was 761-1700 g (mean, $1138 \mathrm{~g}$ ) and males 165-350 g (mean, $205 \mathrm{~g}$ ) (Vogt 1980b).

There is a low, median keel on the carapace without pronounced knobs on the vertebral scutes. The carapace is green, olive or brown, with a variable pattern of green, yellow, or orange lines. Individuals in some populations have dark ocelli on each scute, similar to the pattern of False and Ouachita map turtles, while others have an irregular pattern of dark flecks.

The plastron is smooth and usually yellow or cream and patternless in adult females. Adult males and juveniles have dark lines along the plastral seams. Head, neck, limbs, and tail are dark green and streaked with lighter green, yellow, or orange stripes. A small, roughly triangular, yellow or light green postorbital spot is separated from the orbit by two or three stripes.

Bulté et al. (2013) found that adult males have brighter postorbital spots than adult females, but males did not differ from juvenile females. Circulating testosterone levels in males did not correlate with postorbital spot coloration and the proximate cause of the ontogenetic color change is unknown, but may involve female hormones. Adult males have longer and thicker tails, more prominent vertebral spines, 
and smaller heads than females. Females have a higher and smoother carapace and, in some populations, develop wide heads with broad crushing surfaces on the jaws (Iverson et al. 1989; Lindeman 2000).

Graptemys geographica can be distinguished from $G$. pseudogeographica and G. ouachitensis by its lower carapace keel, immaculate plastron, unique postorbital spot, and more pugnacious behavior. Also, the males lack elongated foreclaws.

The diploid chromosome number is 50 (26 macrochromosomes; 24 microchromosomes) (Killebrew 1977).

Distribution. - Graptemys geographica ranges from the St. Lawrence drainage of southern Canada (Quebec and southern Ontario) and northwestern Vermont westward through Wisconsin and the Great Lake Region into Minnesota (McCoy and Vogt 1990; Powell et al. 2016; TTWG 2017). It ranges south through the Mississippi River Basin in eastern Oklahoma and Kansas to northern Louisiana. It also occurs throughout the Tennessee River Basin, streams above the Fall Line in the Tombigbee River drainage of Alabama, and the Ohio River drainage from Illinois to West Virginia. Disjunct populations occur in the Juniata River and Susquehanna River drainages in Pennsylvania and in the Susquehanna River drainage in Maryland, the Delaware River from Sussex County, New Jersey to its mouth, and the lower reaches of the Hudson River in New York. Extralimital introductions have been recorded in Iowa (Christiansen 2001).

Habitat and Ecology. - Graptemys geographica inhabits rivers and streams in areas of medium to fast current flow, impoundments, and lakes. Although it is sympatric with G.ouachitensis and G.pseudogeographica throughout much of their ranges, G. geographica is often

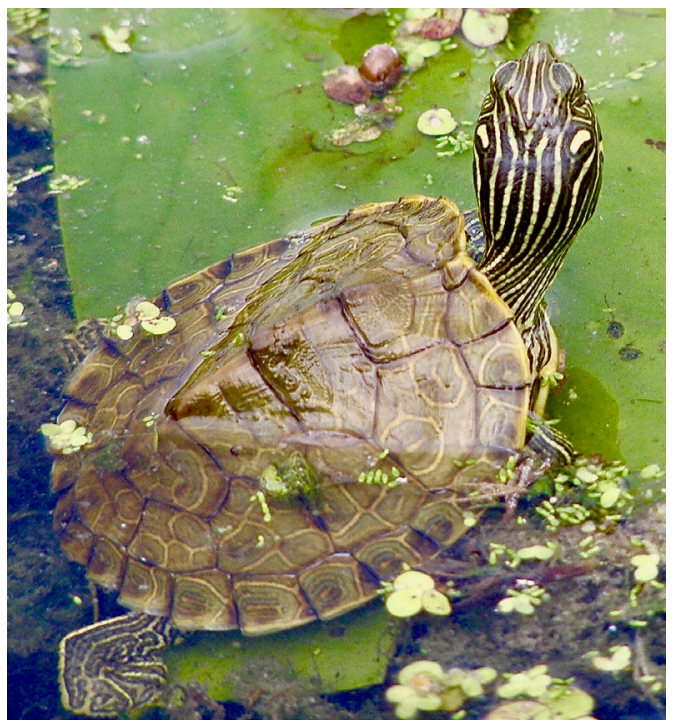

Figure 5. Graptemys geographica juvenile, Dewart Lake, Kosciusko Co.. Indiana, USA. Photo by J.B. Iverson.

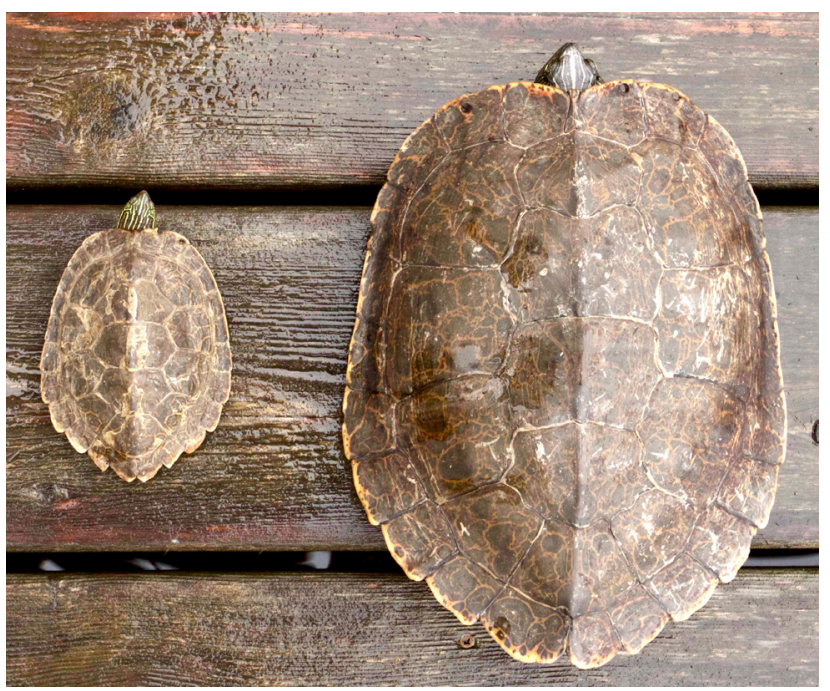

Figure 3. Graptemys geographica sexual dimorphism, Lake Opinicon, Ontario, Canada (adult male on left, adult female on right). Photo by G. Bulté.

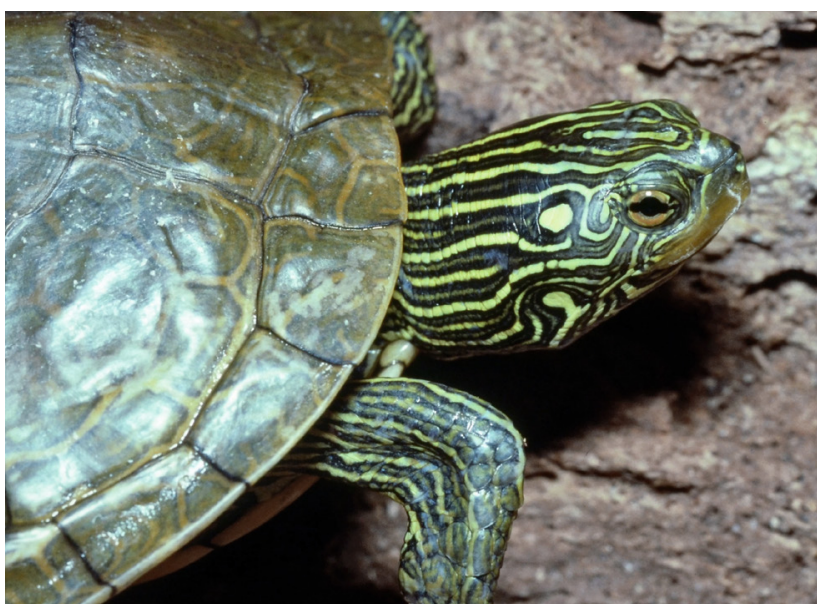

Figure 4. Graptemys geographica male, Dewart Lake, Kosciusko Co.. Indiana, USA. Photo by J.B. Iverson.

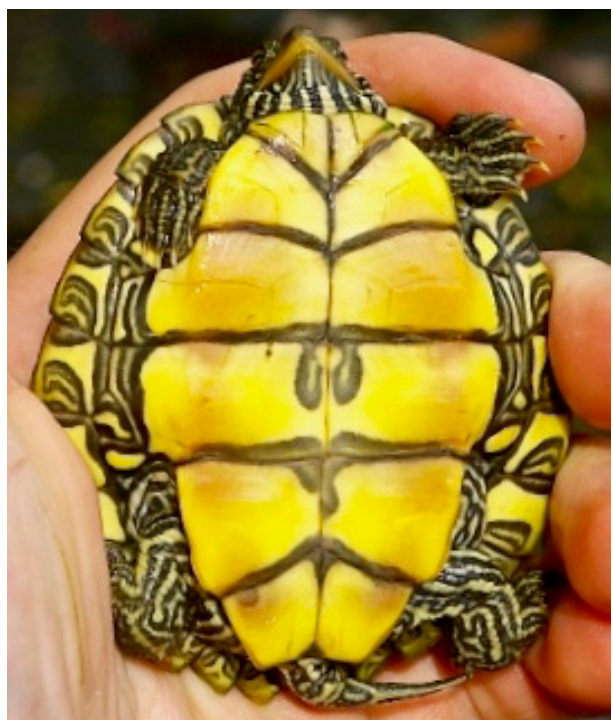

Figure 6. Graptemys geographica juvenile, Quebec, Canada. Photo by M. Ouellette. 


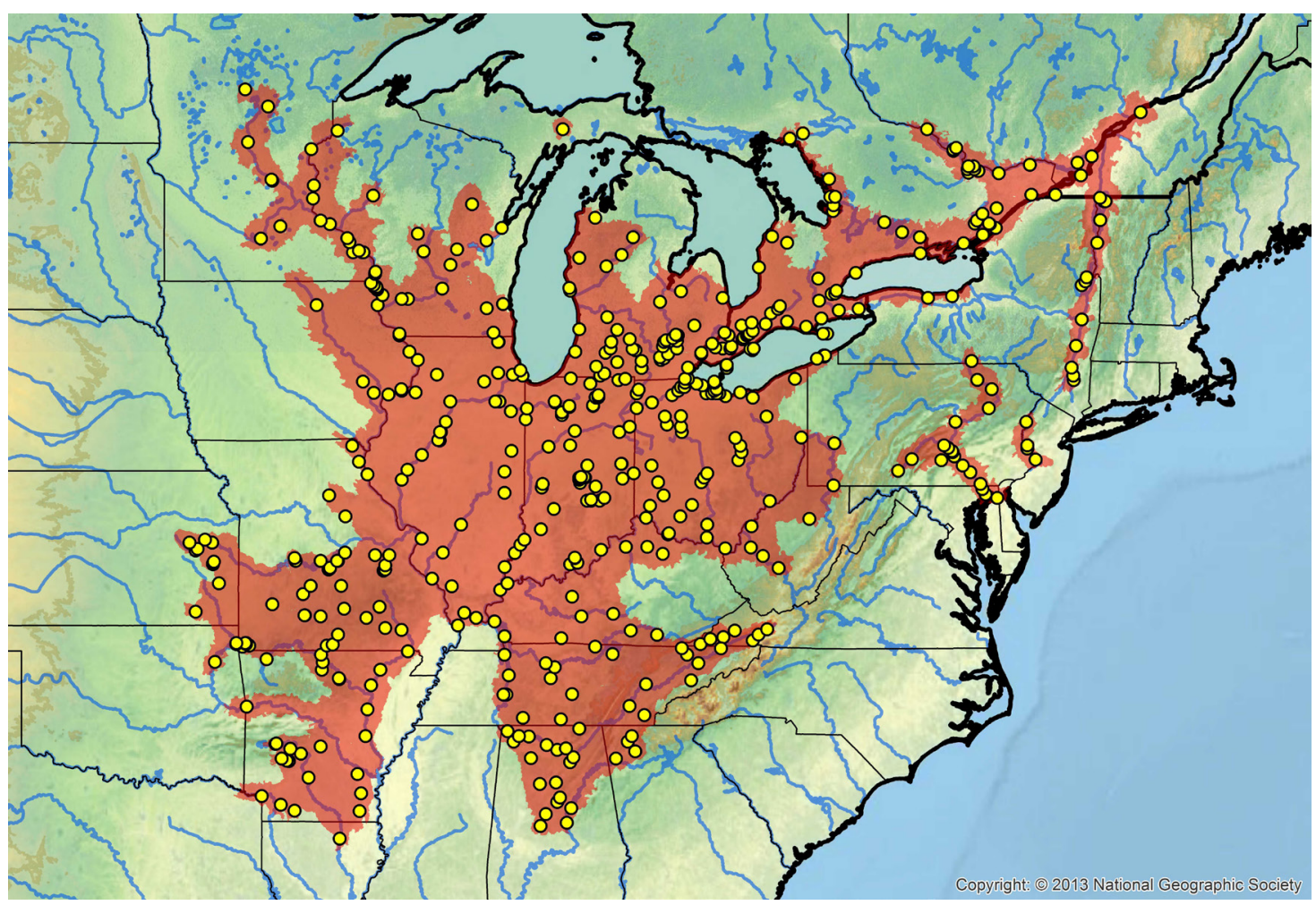

Figure 7. Historic distribution of Graptemys geographica in eastern USA. Yellow dots = museum and literature occurrence records of native populations based on Iverson (1992) and Lindeman (2013), plus more recent and authors' data; red shading = projected historic distribution. Distribution based on GIS-defined level 12 HUCs (hydrologic unit compartments) constructed around verified localities and then adding HUCs that connect known point localities in the same watershed or physiographic region, and similar habitats and elevations as verified HUCs (Buhlmann et al. 2009; TTWG 2017), and adjusted based on authors' subsequent data.

the only species of map turtle found in smaller rivers and lakes (Vogt 1981a).

The species may make extensive movements, depending on season, sex, and size (Gordon and MacCulloch 1980; Flaherty and Bider 1984; Pluto and Bellis 1988). Fuselier and Edds (1994) conducted a study on habitat partitioning of G.geographica, G.ouachitensis, and G.pseudogeographica in Kansas. They collected only 10 G. geographica among 1,503 turtles collected, along with 36 G.pseudogeographica and 169 G. ouachitensis, although they made assertions about $G$. geographica being more common in streams with rock and gravel bottoms, and in areas with more dissolved $\mathrm{CO}_{2}$ and greater acidity. A larger sample size is necessary to confirm these observations, especially since other studies have shown the species to be very dependent on habitats with high dissolved oxygen (Reese et al. 2001; Maginniss et al. 2004). Where it occurs in the Cahaba River in Alabama, the southernmost locality in its range, the stream is highly oxygenated (Vogt, unpubl. data).

Habitat selection has been studied in various parts of the range of G. geographica in different water bodies ranging from small lakes to large river systems (Flaherty and Bider 1982; Pluto and Bellis 1986; Fuselier and Edds 1994; Barrett-Beehler 2007; Ryan et al.2008; Temple-Miller 2008; Carrière and Blouin-Demers 2010). Pluto and Bellis (1986) measured the use of four types of riverine habitats in the
Juanita River in Pennsylvania. From a total of 179 marked individuals and 745 recaptures, $52.9 \%$ of the captures were in a deep and slow area, $17.8 \%$ were in a shallow and slow area, $2.3 \%$ were in riffles, and $27 \%$ in heterogeneous areas where depth and water velocity were variable. The slow and deep area made up $24 \%$ of the study area, suggesting that G. geographica actively selected this habitat.

Using radiotelemetry, Ryan et al. (2008) followed 15 adult females over one active season and to their hibernacula in the Central Canal in Indianapolis, Indiana. They classified the habitats based on the dominant type of land use bordering the canal (woodlots, commercial, residential, open areas) or as the associated river. During the active season, they found that $35 \%$ of turtles had their center of activity adjacent to woodlots, 30\% near commercial areas, $20 \%$ in residential areas, and $15 \%$ in the river, but avoided areas bordered by roads. In winter, $65 \%$ of females hibernated in areas dominated by woodlots, while the remaining $35 \%$ hibernated near residential areas. The authors suggested that the root systems of riparian trees may create more suitable underwater habitat for hibernation. Although the portion of the canal bordered by woodlots was preferred, this study suggested that G. geographica is able to exploit urbanized habitats. The use of commercial areas may be explained by the presence of shoreline stabilized with rip-rap which is used for basking, and the use of residential areas by the 


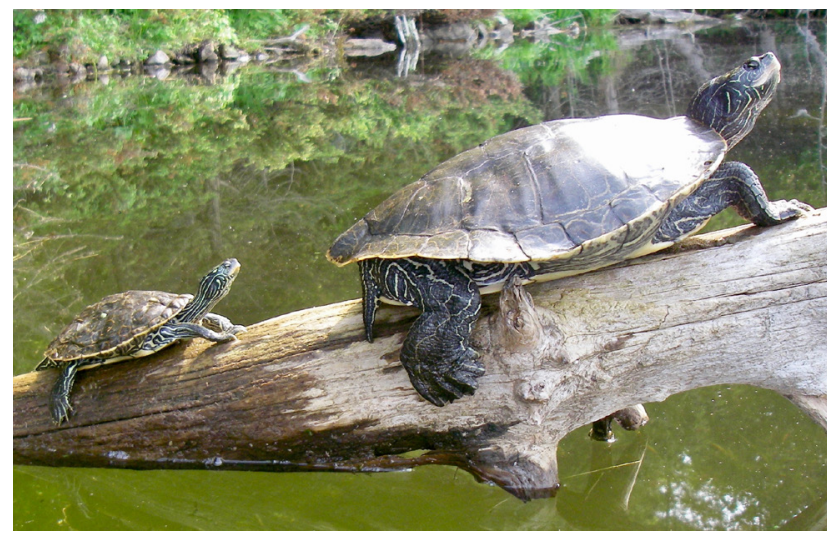

Figure 8. Graptemys geographica male and female basking, Lake Opinicon, Ontario, Canada. Photo by G. Bulté.

availability of suitable nesting sites such as landscaped garden beds.

Temple-Miller (2008) tracked nine female $G$. geographica and 14 female G. ouachitensis in the Scioto River in Ohio and found that G. geographica used habitat with shallower water, coarser substrates, and closer to alcoves or bars than G. ouachitensis. Carrière and Blouin-Demers (2010) followed 12 adult and nine immature females, and seven adult males over two years in the St. Lawrence River in Ontario and measured habitat selection at two spatial scales. At the home range scale, they classified aquatic habitats into four categories: deep ( $>2 \mathrm{~m}$ ) water, intermediate (1-2 $\mathrm{m})$ water, shallow $(<1 \mathrm{~m})$ water, and matted marshes and reeds. The habitat composition of home ranges differed between adult males, adult females, and juvenile females, but in all cases turtles avoided deep water habitats and used the shallow water habitats, marshes and reeds more than they were available. Moreover, the home range of adult and juvenile females included more natural shoreline (as opposed to developed) than expected by chance, indicating that natural shorelines are important for G. geographica, a finding consistent with Ryan et al.(2008). At the microhabitat scale, G. geographica preferred shallow habitats that are close to shore but preference differed among groups, with males having the strongest preference for shallow habitats and adult females having the strongest preference for habitats close to shore. Males also demonstrated a strong preference for habitats with emerging and floating vegetation.

Little is known about habitat selection during hibernation, but G. geographica is considered anoxia intolerant (Jackson et al. 2007), and oxygenated water is essential during hibernation, at least for northern populations (Ultsch 2006). Reese et al. (2001) found that adult females submerged in anoxic water at $3{ }^{\circ} \mathrm{C}$ displayed metabolic acidosis and died after 45 days. In contrast, turtles submerged in normoxic water at the same temperature survived for 5 months without any signs of lactate buildup or decrease in blood $\mathrm{pH}$. Hatchlings are even less tolerant of anoxia than adults. When submerged in anoxic water at $3^{\circ} \mathrm{C}$, hatchlings survived for only 15 days (Reese et al. 2004). The blood chemistry of females hibernating under natural conditions indicated that G. geographica relies on aerobic metabolism during hibernation (Crocker et al.2000). How G. geographica exchanges gases when water bodies are ice-covered is unknown, but may include cutaneous, buccopharyngeal, and cloacal respiration. Graham and Graham (1992) measured oxygen consumption in a hibernating adult male as well as in two hibernating adult females submerged at $3^{\circ} \mathrm{C}$. The male was more active and consumed 2.4 to 2.8 times more oxygen per unit of mass than the females. In absolute terms, however, the males consumed 3.7 to 4.1 times less oxygen than the females because of their much smaller mass (188 g vs 1834 and $1964 \mathrm{~g}$ ). When scuba diving at a communal hibernation

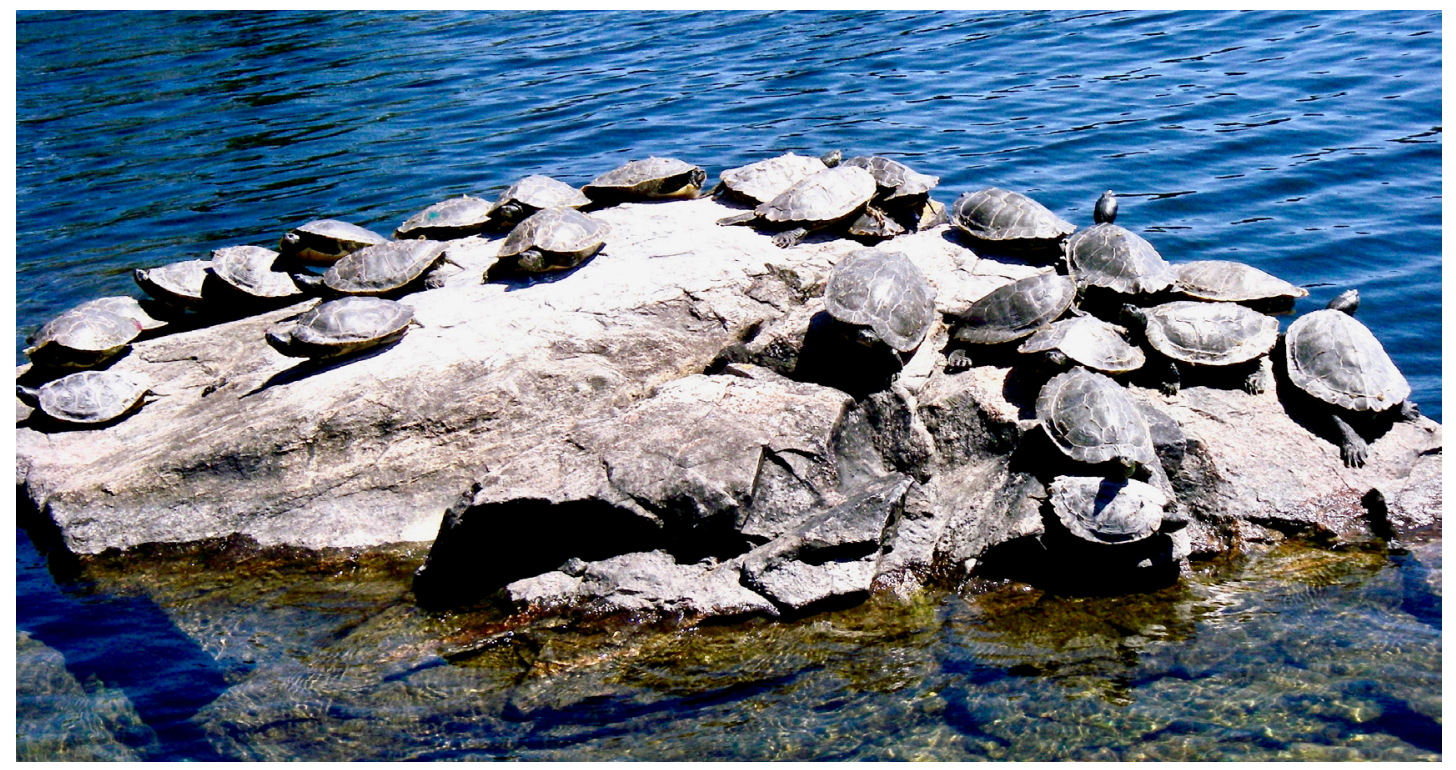

Figure 9. Graptemys geographica females near hibernation site, Lake Opinicon, Ontario, Canada. Photo by G. Bulté. 
site in Vermont, Graham and Graham (1992) noted that males were more active than females, which is expected based on their lower absolute demand for oxygen.

Graptemys geographica has been reported to hibernate communally in Wisconsin (Vogt 1980a), Vermont (Graham and Graham 1992; Ultsch et al. 2000), Pennsylvania (Pluto and Bellis 1988), Maryland (Richards-Dimitrie 2011), and Ontario (Carrière et al. 2009). It is unclear why the species hibernates communally, but it may be an indication that sites with sufficient dissolved oxygen are limited in many areas. Social factors may also explain overwintering aggregations because mating occurs just before and after hibernation (Vogt 1980b). In Wisconsin, G. geographica hibernates behind rock piles and wing dams in areas of flowing water 5-10 m deep from October to mid April (Vogt 1980a). Graham and Graham (1992) described a similar behavior in the Lamoille River, Vermont, where most of more than 100 turtles were congregated at the bottom of a $6.7 \mathrm{~m}$ depression in the river, not buried in the mud. Females were densely congregated, carapace to carapace, and often piled on top of each other. The turtles were not in a deep torpor, but had their necks extended, and moved when disturbed by divers. Only adult turtles were found in this hibernaculum. Map turtles appear to be faithful to their hibernation sites. In Vermont, seven females equipped with sonic tags at a communal hibernation site in November returned to the same site in the subsequent year (Graham and Graham 1992).

Home range size in G. geographica has been reported as either range length or minimum convex polygon area (MCP) (Flaherty 1982; Pluto and Bellis 1988; Graham et al. 2000; Bennett et al. 2009; Ouellette and Cardille 2011; Richards-Dimitrie 2011). Although movements vary greatly within and among studies, G. geographica makes regular upstream and downstream movements. Mean home range length varies from 1210 to $8510 \mathrm{~m}$ in females and from 1658 to $2115 \mathrm{~m}$ in males. Mean MCP area varies from 44 to 366 ha in adult females and from 26 to 217 ha in adult males. Carrière et al. (2009) also reported MCP size for immature females in Ontario to be 200 ha in the St. Lawrence River, and 154 ha in Lake Opinicon, Ontario. Range length varies from 322 to $1950 \mathrm{~m}$ (Flaherty 1982) and MCP from 17 to 1075 ha (Carrière 2007). Pluto and Bellis (1986) found adult males to have a longer range than adult females. In contrast, Carrière et al. (2009) found no difference in home range size and movement patterns between adult males, immature females, and adult females in Lake Opinicon, but found adult females to have larger home ranges than males and immature females, and to move greater distances in the St. Lawrence River. They attributed the larger home range size of females to long distance movements to nesting sites. Such movements have also been reported by Gordon and McCulloch (1980), Pluto and Bellis (1986), and RichardsDimitrie (2011).
The species can move long distances to seek hibernation sites (Vogt 1980b; Graham et al. 2000; Carrière 2007). For instance, a female G. geographica in Wisconsin migrated $4 \mathrm{~km}$ downstream from the hibernaculum behind a wing dam on the Mississippi River to the nesting beach and back again in the fall (Vogt 1980b). Individual females in the Lamoille River in Vermont were found to move a total of 3.1 to $15.4 \mathrm{~km}$ annually, although the length of the home range varied from only 1.5 to $8.0 \mathrm{~km}$ (Graham et al. 2000). A female with a radio transmitter migrated overland at least $500 \mathrm{~m}$ from Lake Opinicon to hibernate in an adjacent lake and returned to Lake Opinicon the following spring (Bulté, unpubl. data).

Smith and Iverson (2004) found that G. geographica is more active before noon than in the afternoon. As for most emydid species studied, G. geographica displays a pronounced aerial basking behavior and juveniles and hatchlings are also known to bask (Janzen et al. 1992). The primary purpose of basking is assumed to be thermoregulation, but basking also helps rid the shell of algae and leeches, and can provide an opportunity for commensal birds (grackles) to clean leeches from the turtles' bodies (Vogt 1979). Under laboratory conditions, Ben-Erza et al. (2008) found that adults and hatchlings can swim near their maximal speed over a broad range of temperatures $\left(16\right.$ to $37^{\circ} \mathrm{C}$ for adults and 21 to $33^{\circ} \mathrm{C}$ for hatchlings). Nutting and Graham (1993) estimated the preferred body temperature of G. geographica to be $27.7^{\circ} \mathrm{C}$ (range $18.2-32.9^{\circ}$ ) which is close to the optimal range for energy assimilation of 28.7 to $32.5^{\circ} \mathrm{C}$ estimated by Bulté and Blouin-Demers (2010a). Bulté and Blouin-Demers $(2010 \mathrm{a}, \mathrm{b})$ measured the body temperature of free ranging adult males and females as well as immature females in Ontario using surgically implanted temperature loggers. They found that basking is necessary for turtles to reach their optimal temperature throughout the active season. Moreover, the amount of time spent at the optimal temperature affects the growth rate of immature females. Basking was estimated to increase net energy retention by 17 to $32 \%$. Early spring basking is particularly important to accelerate vitellogenesis and ovulation in females (Vogt 1980b). In May, basking allowed map turtles to maintain their body temperature on average $4-6^{\circ} \mathrm{C}$ above the maximum water temperature for 6 to $7 \mathrm{hrs}$ per day and to reach a body temperature up to $17^{\circ} \mathrm{C}$ above the water temperature (Bulté and Blouin-Demers 2010a). In Canada adult females spend a mean of 8 to 9 hrs per day basking in early May and early June compared to approximately 5 hrs in early July to early August (Jain-Schlaepfer et al. 2016).

Graptemys geographica can be found basking from mid-April to October in Wisconsin, often in mixed species groups with False and Ouachita map turtles (Vogt 1981b). Congregations of these turtles can often be observed on the same log, one on top of another. Graptemys geographica 
basks predominantly on rocks and logs, although in Indiana juveniles and males often bask on lily pads or other floating vegetation (Iverson, pers. obs.). Lindeman (1999) suggested that not all riparian areas are used equally by Graptemys species and that they selected specific basking habitat based on current speed and channel morphology. Flaherty and Bider (1982) found that basking sites used by G. geographica in a Quebec fluvial lake were larger and further away from shore and from vegetation than unused sites. Similarly, Pluto and Bellis (1986) found that G. geographica in Pennsylvania preferred to bask at sites away from shore, but smaller turtles (males and immature females) tended to bask closer to shore than larger females. Peterman and Ryan (2009) found G. geographica to prefer basking on rocks as opposed to deadwood or vegetated banks in a canal in Indiana. They also reported map turtles to commonly bask on shores stabilized with rip-rap.

Graptemys geographica may share basking sites with other species of turtles, including Chrysemys picta (Bulté, pers. obs.), Apalone spinifera (Vogt, pers. obs.), and Glyptemysinsculpta (Hartzell2017).Aggressive interactions during basking, in which larger turtles dislodge smaller ones from basking sites, have been reported by Pluto and Bellis (1986). Graptemys geographica is extremely wary when basking; if one is frightened and dives into the water, the rest follow. It has generally been assumed that the stimulus was visual, but since turtles are known to vocalize, other explanations should be pursued. Graptemys geographica also basks at the surface of the water, usually in mats of floating vegetation. Out of 3077 observations from 53 individuals followed by radiotelemetry in Lake Opinicon, Bulté et al. (2010) observed aquatic basking in 23\% of them.

Diet. - Graptemys geographica is primarily carnivorous. It forages in 1-2 $\mathrm{m}$ of water during the day, gleaning prey from plants and submerged tree trunks or on the river bottom (Vogt 1981b). Snails were reported to be the dominant prey item in Indiana (Newman 1906), Illinois (Cahn 1937), Michigan (Lagler 1943), Wisconsin (Vogt 1981b), Missouri (White and Moll 1992), Ontario (Bulté et al. 2008a,b), and Maryland (Richards-Dimitrie et al. 2013). Other prey items include bivalves, insects, crayfish, and fish (Garman 1890; Newman 1906; Surface 1908; Lagler 1943; Vogt 1981b; White and Moll 1992; Lindeman 2006; Richards-Dimitrie et al. 2013). Crayfish made up $24 \%$ of the food consumed by map turtles in the eastern United States (Penn 1950). Newman (1906) and Cahn (1937) reported that basking G. geographica catch flying insects while basking, but Moll (1976) suggested that basking turtles rapidly move their heads while basking as a response to bothersome insects and not as an attempt to catch them.

Females, in addition to being larger than males, have relatively larger heads and wider alveolar crushing surfaces
(Lindeman 2000; Lindeman and Sharkey 2001) with more powerful jaws (Bulté et al. 2008b), allowing them to feed on larger, harder prey items. Adult males eat smaller mollusks and more insects than adult females, particularly caddis fly larvae (Trichoptera; Lindeman 2006, Bulté et al. 2008a, Richards-Dimitrie et al. 2013). Females exhibit an ontogenetic shift in diet toward larger and harder prey items (Bulté et al. 2008a,b; Richards-Dimitrie et al. 2013).

Invasive mollusks have altered the diet of G.geographica in many areas. The proportion of invasive dreissenid mussels (Zebra Mussel,Dreissena polymorpha, and Quagga Mussel, D. bugensis) in the diet of females increases with size and adult females feed almost exclusively on these invasive bivalves in Lake Erie (Lindeman 2006). Up to $36 \%$ of the diet of adult females is composed of Zebra Mussels in Lake Opinicon (Bulté and Blouin-Demers 2008). In contrast, the diet of males is composed of less than $5 \%$ of dreissenids in both lakes Erie and Opinicon. Whether G. geographica can serve as a biocontrol on dreissenids is unknown, but data from Lake Opinicon suggest that turtle predation at natural population levels has a negligible impact on the abundance of Zebra Mussels (Bulté, unpubl.data).Increasing population sizes of map turtles would likely make them formidable consumers of this invasive species.

Parasites. - Lindeman(2013) reviewed the eukaryotic parasites of Graptemys species. Graptemys geographica has been reported to host two species of leeches (Saumure and Livingston 1994; Graham et al. 1997; Poly 1999; Ryan and Lambert 2005), six coccidians (DeGuisti and Batten 1951; Pluto and Rothernbacher 1976; Wacha and Christiansen 1976), a trypanosome (Woo 1969), one monogenean (Hughes et al. 1942), eight trematode flukes (Stunkard 1917, 1921, 1922; Harrah 1922; Horsfall 1935; Hsû 1937; Hughes et al. 1942; Rausch 1946, 1947; Brooks 1979), one enteric spy-headed worm (Van Cleave 1913; Hopp 1946, 1954; Cable and Hopp 1954; Fisher 1960), and six round worms (Rausch 1947; Limsuwan and Dunn 1978). In a hibernating group of 208 female G. geographica in the Lamoille River in Vermont (Graham et al. 1997), 151 had at least one leech attached to it. Broods of up to 153 leeches were found attached to the plastron of some turtles. The prevalence of leeches was 50.6\% (39 of 77) in an urban habitat in Indiana (Ryan and Lambert 2005) and 5.4\% (8 of 148) in the St. Lawrence River in Ontario (Reshke 2009). The emydid herpes virus 1 (EmyHV-1) has been confirmed to infect G. geographica and appears to have caused mortality in one captive juvenile individual (Ossiboff et al. 2015). Hernandez-Divers et al. (2009) isolated the bacterium Aeromonas hydrophila from the shell of a G.geographica. The species is also host to epizoophytic algae (Edgren et al. 1953; Colt et al. 1995), and Zebra Mussels have been noted to attach to their carapace during hibernation (Lindeman 2017). 
Growth and Maturity. - The marked sexual size dimorphism of G. geographica is associated with important intersexual differences in size and age at maturity. Age has been estimated either from growth models derived from growth intervals and/or from growth ring counts. Growth rings are accurate for estimating the age in this species only up to age six in males and twelve in females (Vogt 1980b). Vogt (1980b) found mature males to be at least 4 years old in Wisconsin. Males were estimated to require 3 to 5 years to reach maturity in Indiana (Iverson 1988), 4 to 5 yrs in Ontario (Bulté and Blouin-Demers 2009), and 2 yrs in Pennsylvania (Lindeman 2013). Size at maturity for females was estimated to be $87 \mathrm{~mm} \mathrm{CL}$ (converted from 75 $\mathrm{mm}$ PL) in Quebec and Ontario (Gordon and McCulloch 1980; Bulté and Blouin-Demers 2009) and 93 mm CL in Wisconsin (Vogt 1980b). Females were estimated to take 9 to 10 yrs to mature in Indiana (Iverson 1988), 10 to 13 yrs in Ontario (Bulté and Blouin-Demers 2009), 9 yrs in the Juanita River, Pennsylvania (Nagle and Congdon 2016), and 8 yrs in Lake Erie, Pennsylvania (Lindeman 2013). Vogt (1980b) reported two immature females at 10 and 12 yrs in Wisconsin, suggesting that females require at least 13 yrs to mature at that locality. Delayed maturity of females from that population may reflect the reduced mollusk fauna (Vogt 1981a). The smallest females with eggs were $196 \mathrm{~mm}$ CL in Quebec (converted from 175 mm PL from Gordon and McCulloch 1980), 210 mm CL in Wisconsin (Vogt 1980b), 200 mm CL in Ontario (Bulté and Blouin-Demers 2009) and $172 \mathrm{~mm}$ CL in Pennsylvania (Nagle and Congdon 2016).

Some confusion exists regarding sexual differences in growth rate in map turtles. Various studies have claimed that females grow faster than males, but this appears to be the case only after males have reached sexual maturity. Before males reach sexual maturity, growth rates are in fact the same between males and females. Vogt (1980b) reported the same growth rate for males and females for four years, until males reach maturity in Wisconsin. Similarly, Iverson (1988) found that males and females in Indiana grew at the same rate during the first two years but females grow much more rapidly once the males reached sexual maturity. In Ontario, Bulté and Blouin-Demers (2009) found males estimated to be mature or nearly mature to grow at a much slower rate than females of the same size.

Reproduction. - Copulation takes place in both spring and fall (Vogt 1980b). This species, like all species of Graptemys studied, has a stereotyped species-specific courtship display; however, the male does not drum his foreclaws against the ocular regions of the female as in other species of map turtles. Instead, males bob their heads up and down rapidly in the vertical plane while in snout-to-snout contact with the female (Vogt 1980b). Bulté et al. (2018) recorded the response of free ranging males to female decoys of two different sizes during the spring mating season and found evidence that males prefer larger females when given the choice. Banger et al. (2013) found that 10 of 14 clutches collected over one nesting season were sired by two or three males.

Like most North Temperate Zone turtles, G. geographica enters hibernation with complete sets of enlarged yolked follicles (Vogt 1980b). They emerge from hibernation in mid-April, and spend several weeks basking to hasten follicle development and ovulation of the first clutch of eggs in late May. Over an 8-year study in Pennsylvania, nesting females were found as early as 22 May and as late as 1 August (Nagle and Congdon 2016). The final nests for the season are finished by mid-July in Wisconsin (Vogt 1981a).

Two to three clutches are produced annually in Wisconsin, southern Missouri, and Pennsylvania (Vogt 1981a; White and Moll 1991; Nagle and Congdon 2016). In Pennsylvania, 12 to $21 \%$ of females produced 2 clutches and only $0.5 \%$ produced three clutches, and clutches were deposited at intervals of at least 13 days (Nagle and Congdon 2016). Clutch size was reported to range from 10 to 20 eggs (mean $=12)$ in Wisconsin (Vogt 1980b); 6 to 15 (mean 10.6) in Pennsylvania (Nagle and Congdon 2016); 6 to 15 (mean = 10.1) in Missouri (White and Moll 1991); 10 to 16 in Illinois $($ Cahn 1937); 9 to 17 (mean = 12) in Quebec (Gordon and MacCulloch 1980); and 3 to 21 (mean =11.9) in Lake Erie, Pennsylvania (Ryan and Lindeman 2007).

Eggs are ellipsoidal and have flexible shells. Eggs from the Mississippi River, Wisconsin, measured 34-38 x 22-26 mm (Vogt 1981a). Mean egg length from Indiana $(n=180)$ was $36.4 \mathrm{~mm}$ (range 29.3-42.8) and mean width $22.9 \mathrm{~mm}$ (range 19.1-25.8); eggs weighed 11.2 g (range 6.4-14.5; $\mathrm{M}$. Ewert and Iverson, unpubl. data). Mean dry mass of eggs in Michigan contained 66\% lipids (Congdon el al. 1983).

Nesting occurs throughout the day but peaks during midmorning in Pennsylvania. Females take from 61 to $143 \mathrm{~min}$ (mean $=82.4 \mathrm{~min}$ ) to nest; from beginning of excavation to departure (Nagle and Congdon 2016). Nesting takes place from early evening to late morning on the Mississippi River in Wisconsin, and may continue throughout the day on overcast days (Vogt 1981a). Nests are dug 11.6 to $76.2 \mathrm{~m}$ (mean = $29.5 \mathrm{~m}$ ) from the river in Pennsylvania (Nagle and Congdon 2016), in a variety of substrate types including limestone gravel overlaying or mixed with soil, coal slag, shale, sands, and clay (Nagle et al. 2004). Steen et al. (2012) reported an average distance between nesting females and water of $35.7 \mathrm{~m}$ (range 9 to 252) for 19 females from Ontario. Nests are flask-shaped and 8.0-16.5 cm deep (Nagle et al. 2004; Baker et al. 2010).

Sex is determined by incubation temperature in this species, males being produced in cooler shaded nests and from nests laid later in the season, and females being produced in warmer nests in the sun (Bull and Vogt 1979; Vogt and Bull 
1984).Eggs incubated in the laboratory produced all males at $28^{\circ} \mathrm{C}$ and all females at $30^{\circ} \mathrm{C}$; the threshold temperature was estimated to be $28.5^{\circ} \mathrm{C}$ for the Mississippi River population in Vernon Co., Wisconsin (Bull et al. 1982). Lindeman (2013) reviewed estimates of secondary (all sexed individuals) and functional sex ratio (mature individuals only) for populations across the species range. The secondary sex ratio (proportion of males) varied from 0.28 to 0.63 , but did not deviate from 1:1 in most populations. Both Browne and Hecnar (2007) and Bennett et al. (2009) reported significant biases toward females in the field, whereas Gordon and McCulloch (1980) reported a significant bias toward males, with the functional sex ratio ranging from 0.16 to 0.75 . Vogt (1980b) reported a functional sex ratio significantly biased toward males, while Tran et al. (2007) reported a significant bias toward females. Bulté and Blouin-Demers (2009) reported a 1:1 functional sex ratio.

The sex ratio of hatchlings and intersexual differences in survivorship may explain part of the variation in sex ratio among populations, but sampling bias might also account for part of the variation. However, the existence of sampling bias can be determined by mark and recapture studies to test if there is a sexual or size capture bias or not by the number of recaptures of each sex in relation to the number of each sex that were marked. Using unbaited fyke nets of different diameters and lead sizes has proven to be the most unbiased technique for sampling freshwater turtle populations (Vogt 1980a, 2012).

Eggs hatch in the late summer and early fall and hatchlings emerge from the nest predominantly in the following spring (Gibbons and Nelson 1978; Baker et al. 2003, 2010, 2013; Nagle et al. 2004; Gibbons, 2013) but fall emergences were also reported (Baker et al.2003; Nagle et al. 2004) and hatchlings with umbilical scars were found in late August and September in northern Indiana (Iverson, unpubl. data) and Wisconsin (Vogt 1981b). Emergence occurred 289 to 346 days (average $=333$ ) after nest construction in Pennsylvania (Nagle et al. 2004). Mean emergence date in northern Indiana was 25 April and hatchlings from the same nest emerged up to 18 days apart (mean $=11$ days; Baker et al. 2010).

Hatchlings are nearly round when hatched. Hatchlings $(n=350)$ measured in the spring from natural nests in Pennsylvania measured $30.2 \mathrm{~mm}$ CL (25.2-33.3), 27.5 mm plastron length (22.9-30.2), $15.2 \mathrm{~mm}$ carapace height (13.0-16.8), $27.9 \mathrm{~mm}$ carapace width (21.3-31.8) and weighed $6.4 \mathrm{~g}$ (4.2-8.2) (Nagle et al. 2004). The degree of melanization of hatchlings of eight species of freshwater turtles, including those of G. geographica, was shown to be influenced by the darkness of the substrate on which they were reared (Rowe et al. 2014).

Pappas et al. (2017) used artificial nests to study the visual cues associated with nest dispersal in hatchlings of five species of turtles, including G. geographica. The three species of map turtle studied dispersed toward nearby dark forested horizons that led them away from the main river channel. The authors suggested that hatchlings move toward darker horizons in the search for lentic vegetated wetlands with fewer large predators and higher productivity than the main river channel. Their results also suggest that $G$. geographica has a distance perception of 230 to $280 \mathrm{~m}$. Whitear et al. (2017) found no evidence that hatchlings of G. geographica can recognize conspecifics and close kin from chemical cues alone.

Nest temperatures over the winter were recorded in Indiana (Baker et al. 2003, 2010) and Pennsylvania (Nagle el al. 2004). At both localities, nests regularly experienced subzero temperatures, with minimum temperatures reaching $-5.4^{\circ} \mathrm{C}$ in Indiana and $-8.4^{\circ} \mathrm{C}$ in Pennsylvania. Freeze tolerance is poor in this species and hatchling survival under prolonged subzero temperatures is attributed to freeze avoidance (supercooling; Storey and Storey 2017). Under experimental conditions, Baker et al. (2003) found that none of the hatchlings exposed to $-2.5^{\circ} \mathrm{C}$ for $24 \mathrm{hrs}$ recovered when somatic freezing was induced. Similarly, Dinkelacker et al. (2005) found $50 \%$ mortality after a 3 -day exposure at $-2.5^{\circ} \mathrm{C}$. However, in the absence of ice nucleating agents, freezing occurred at $-14.8^{\circ} \mathrm{C}$ and hatchlings remained unfrozen for $33 \mathrm{hrs}$ at $-8^{\circ} \mathrm{C}$ and for 5 days at $-6^{\circ} \mathrm{C}$ (Baker et al. 2003). To avoid freezing, hatchlings must purge their body from ice nucleating agents (Baker et al. 2003). Nest site selection by females, particularly the moisture content of the soil, may also be important to protect hatchlings from freezing. Under experimental conditions, hatchlings in soil with $0 \%$ moisture froze on average at $-10.3^{\circ} \mathrm{C}$, but froze at temperatures near $0^{\circ} \mathrm{C}$ when the soil moisture content was $16 \%$ (Baker et al. 2003). Females may select dry nesting sites in which ice crystals triggering freezing are less likely to form (Baker et al.2003). In addition, the nests of G. geographica in Indiana are deeper than those of sympatric painted turtles (which are freeze tolerant) and experience slightly warmer winter temperatures which reduce the risk of freezing (Baker et al. 2010). The relatively high cold hardiness of G. geographica hatchlings may explain why the range of this species extends farther north than any other Graptemys species.

Predation. - Females and eggs are preyed upon by red fox, raccoon, and otters (Vogt 1980a). Geller (2012) used trail cameras to monitor nests of G. geographica and $G$. ouachitensis during four nesting seasons in Wisconsin and documented 38 depredation events out of 42 nests. Raccoons (Procyon lotor) were the only predator recorded while depredating a nest, but striped skunks (Mephitis mephitis), Virginia opossums (Didelphis virginiana), coyotes (Canis latrans), and American crows (Corvus brachyrhynchos) were recorded at the sites and may have contributed to nest depredation. Most nests (74\%) were depredated during the 
night following their construction. Fly predation is also responsible for the mortality of many eggs in Wisconsin; sarcophagid fly larvae enter the pipped eggs or eat their way into the living egg and eat the hatchling turtle alive before it can leave the egg (Vogt 1980c). Non-predatory fly larvae have been reported in a failed nest from Ontario (Saumure et al. 2006). Hatchlings are consumed by many birds (ring-billed gulls, herons, crows, grackles, and red-winged blackbirds), fish, and rice rats (Oryzomys palustris) (Goodpaster and Hoffmeister 1952; Vogt 1980b).

Population Status. - Many populations are stable in the northern part of the range where humans do not prey upon them (Vogt 1981a). Estimates of density have been made for various parts of the range of G. geographica and are quite variable. This variation may be attributable to variation among studies in sampling methods and effort as well as variation in habitat quality and productivity. Estimates of density include 2.7 to 18.4 turtles/ha along a waterway fragmented by locks and dams in Ontario (Bennett et al. 2009), 5.7 to 14.4 turtles/ha in a river in Missouri (Pitt and Nickerson 2013), 2.5 turtles/ha in a reservoir in Tennessee (Weber and Layzer 2011), 2.2 turtles/ha in a fluvial lake in Quebec (Gordon and McCulloch 1980), 1.9 turtles/ha in a small lake in Ontario (Bulté et al.2010), and 0.2 turtles/ha in the St. Lawrence River in Ontario (Bulté et al. 2010). Densities per $\mathrm{km}$ of shoreline have been estimated at 59 turtles $/ \mathrm{km}$ in an Ozark stream (Nickerson et al. 1984), 27 turtles/km in a Pennsylvania River (Pluto and Bellis 1988), and 15 turtles/km in a Quebec lake (Gordon and MacCulloch 1980). These estimates appear to be much lower than the populations on the Mississippi River at Stoddard, Wisconsin, in the 1960s and 1970s; the populations of all three species of Graptemys there were too abundant to begin speculation on the density or biomass without a more extensive mark and recapture study (Vogt 1980b). Graptemys geographica was apparently still as abundant in the Mississippi River at Stoddard, Wisconsin, and Weaver, Minnesota in July 2011, as it was in the 1970s (Vogt, unpubl. data). A 38-year study of a lentic population in Indiana (Iverson 1988; Smith and Iverson 2004; Smith et al. 2006; Iverson, unpubl. data) reported map turtles to be common, reproducing, and growing similar to what they were in the 1980s. Populations in the Juniata River in Pennsylvania (Pluto and Bellis 1988) appeared to be doing well. In the Mississippi River where the species is abundant, hatchlings are not commonly found away from the nesting beaches, but this in itself may not be sufficient evidence to say that successful reproduction or recruitment is not occurring (Vogt 1980a; Vogt, unpubl. data).

The relative abundance of $G$. geographica within turtle assemblages has been reported in numerous studies (Newman 1906; Wade and Gifford 1964; Daigle et al. 1994; Fuselier and Edds 1994; Lindeman 1997, 1998, 2013, 2015;
DonnerWright et al. 1999; Anderson et al. 2002; Tucker 2004; Dreslik et al. 2005; Smith et al. 2006; Rizkalla and Swihart 2006; Browne and Hecnar 2007; DeCantanzaro and Chow-Fraser 2010; Duchak and Holzapfel 2011; Gooley et al. 2011; Weber and Layzer 2011; Bluett et al. 2013). The species constituted less than $1 \%$ of all captures in baited hoop nets in Kansas (Fuselier and Edds 1994) and Central Illinois (Bluett et al. 2013), whereas it constituted $65 \%$ of captures in hoop traps and basking traps in Lake Erie in Pennsylvania (Lindeman 2013). In Quebec, 62\% of observations at basking sites were of G. geographica (Daigle et al. 1994). Spotting scope surveys of basking turtles in the Tennessee River by Lindeman $(1997,1998)$ found G. geographica to be the least abundant species seen, only $0.06 \%$ of 1757 basking turtles sighted. Graptemys geographica represented about $7 \%$ of the catch of the three species of map turtles collected by fyke nets, gill nets, and trammel nets in the Mississippi River at Stoddard in the 1970s (Vogt 1980a). The variation in relative abundance among studies is important and likely reflects variation in the structure of turtle assemblages as well as variation in surveying methods (e.g., Browne and Hecnar 2005). For a recent review on turtle capture methods refer to Vogt (2012).

Threats to Survival. - Graptemys geographica is associated with large lakes and rivers where collisions with powerboats can be a serious threat. In Indiana, Smith and Iverson (2004) reported evidence of propeller injuries in up to $16 \%$ of their annual captures over a 12 -yr period, but the prevalence of injuries did not increase over time. The rate of injuries reported by Bulté et al. (2010) and Bennett and Litzgus (2014) ranged from 6.8 to $28.6 \%$ for adult females, 1.7 to $12.8 \%$ for males, and 1.4 to $2.7 \%$ for juveniles. In both studies, adult females were more likely than males and juvenile females to have scars from boat propellers. This bias may be due to the tendency of adult females to use open water and to bask in beds of floating vegetation more than males and juveniles (Bulté et al. 2010). The larger size of adult females may also make them more likely to survive a propeller strike because carapace strength increases exponentially with size (Speck 2015). Alternatively, females may be more likely to be hit due to their larger size.

Basking disturbance can have important consequences to the energy budget of G. geographica. Jain-Schlaepfer et al. (2016) modeled the energetic consequences of basking disturbances for a population near the northern limit of its range. Disturbances had the greatest energetic consequences in the spring. In early May, G. geographica experienced on average 0.15 disturbances per hour which reduced metabolic rate by $7.8 \%$ and a rate of one disturbance per hour would lead to a $39 \%$ decrease in metabolic rate. Regular basking disturbances in the spring could slow vitellogenesis and 
delay oviposition and hatchling. Boat disturbances in the warmer months had little effect on body temperature and metabolism, however.Graptemys geographica may become habituated to high boat traffic. In a no-wake zone of Lake Erie, Lindeman (2013) observed that boats could approach basking G. geographica within 10-20 m without causing them to abandon their basking site. In the White River in Missouri, Nickerson et al. (1984) commented that the commercial canoe tours on the river severely reduced the population of G. geographica.

Fisheries by-catch may be a threat in certain areas. In Wisconsin, hundreds of map turtles were often collected per day in gill nets set for carp (Vogt 1980). Map turtles are also occasionally captured in fyke nets used in commercial fisheries (Carrière et al. 2006; Gislason et al. 2010; Larocque et al. 2012a; Wieten et al. 2012; Midwood et al. 2015). Carrière et al. (2006) found 16 dead G. geographica in commercial fishing fyke nets in the St. Lawrence River in a single week. Gislason et al. (2010) monitored commercial fishing fyke nets for by-catch in Long Point Bay, Lake Erie, Canada, and reported a catch per lift of 0.15 individuals for G. geographica.Graptemys geographica appears to be less likely to be captured than other species in hoop nets (Cairns et al. 2013), but when captured it suffers comparatively high behavioral impairment and physiological stress (Stoot et al. 2013). Low rates of female mortality in fishing nets can have severe consequences at the population level. Midwood et al. (2015) estimated that a mortality rate of 10 females per year would cause the local extinction of a population of approximately 1500 individuals within 50 years. The species may be particularly vulnerable to bycatch mass mortality because of its tendency to form large aggregations at hibernation and nesting sites. Fishing nets set near such communal sites could result in even higher by-catch and mortality. Catrysse et al. (2015) reported that during a four-week period the bodies of 35 adult females were found stranded on the north shore of Lake Erie in Ontario. Although the cause of mortality could not be determined, fisheries by-catch could not be excluded as a potential cause.

Commercial collecting of G. geographica has not been reported regularly. However, a report from Iowa in 1991 noted that about $5,265 \mathrm{~kg}$ of all species of turtles were taken from the upper Mississippi River, as reported from the 40 current licenses to collect turtles issued that year. Between1989 and 1992, 36 G. geographica made up 25\% of the 145 turtles reported in harvest (Gritters and Mauldin 1994). In a series of papers, Pitt and Nickerson reported on the population size of G. geographica in the North Fork of the White River in Missouri in 1969, 1984, and 2004-2007 (Pitt and Nickerson 2012, 2013, 2014; Nickerson and Pitt 2013). Their results suggested that the population declined by nearly $50 \%$ between 1969 and 2004 but fully recovered between 2005 and 2007. Based on anecdotal evidence, the authors attributed the decline to harvesting for the food trade and the recovery on the cessation of harvesting. Although harvesting may have impacted the population, the scale of the decline and the seemingly rapid recovery should be viewed with caution because the relatively small number of captures in every sampling year may have resulted in inaccurate and/ or imprecise estimates of population sizes.

Dams and locks may impede the movement of $G$. geographica. Bennett et al. (2010) found the home ranges and movements of female G. geographica to be $82 \%$ and $73 \%$ smaller on average in a fragmented section of the Trent Severn Waterway in Ontario, compared to unfragmented sections of the same waterway. Richards-Dimitrie (2011) also suggested that dams impede the movements of females in the Susquehanna River, Maryland. Moreover, fragmentation appears to have negatively affected the growth rate of males and juvenile females as well as the population sex ratio in the Trent Severn Waterway (Bennett et al. 2009).

Changes in the diet of G. geographica brought about by the introduction of invasive species and the decline of native mollusks is a potential concern. Invasive dreissenid mussels have become an important component of the diet of G. geographica, particularly of adult females (Lindeman 2006; Bulté and Blouin-Demers 2008; Iverson, pers. obs.), but the impacts of this alternate diet on the energy budget and toxicology of the species remain largely unknown. Dreissenid mussels have greatly altered the communities of aquatic invertebrates (Ward and Ricciardi 2007; Higgins and Vander Zanden 2010) and it is not clear whether they are a preferred or secondary prey of G. geographica.Zebra Mussels are not as nutritional as some native snails, and captive reared map turtles consumed Zebra Mussels at a slower rate when a common native snail,Bythinia tentaculata, was present (Serrouya et al. 1995). Zebra Mussels may not be a primary choice of map turtles but their lower energy density may be outweighed by their high abundance. In Lake Opinicon, Ontario, the diet shift cause by Zebra Mussels does not appear to have affected the reproductive output of female G. geographica (Bulté and Blouin-Demers 2008). Predation on Zebra Mussels by other taxa has led to both increases and decreases in the ingestion and accumulation of contaminants such as PCBs (Mazak et al. 1997; Mercer et al. 1999), but the toxicological impacts on G. geographica are unknown. In fact, studies examining contaminant exposure and accumulation in G. geographica are nonexistent. The effects of the replacement of native bivalves by the introduced Zebra Mussel on the diet and status of map turtles as well as the potential use of map turtles as a biological control agent deserve study.

The dramatic decline of the North American mollusk fauna, particularly freshwater snails, is a potential source 
of concern for G. geographica. Seventy-four percent of freshwater snail species in North America are imperiled (Johnson et al. 2013). Habitat alterations and destruction, invasive species, and water pollution are the main causes of decline (Johnson et al. 2013). Whether the local declines of gastropods have negatively impacted populations of $G$. geographica is largely unknown, but Moll (1977) found that mollusk consumption was reduced after 80 years of habitat degradation and subsequent loss of snails and clams in Meredosia Lake in the Illinois River Basin; the only mollusk remaining in the diet of G. geographica was the introduced Asian Clam (Corbicula sp.).

Female G.geographica are often killed while attempting to cross roads to reach nesting areas (Ashley and Robinson 1996; Conner et al. 2005; Steen et al. 2006; Choquette and Valliant 2016). Removal of snags and logjams from rivers to improve recreational use and maintain channels for commercial barge traffic, channelizations, construction of impoundments, industrial pollution, and siltation, all affect populations of G. geographica negatively (Bodie 2001; Lindeman 1999; Smith et al. 2006; Vandewalle and Christiansen 1996). Some populations are apparently at risk because of increased predator populations (Cochran 1987).

Exposure to contaminants as well as thermal alteration of nesting substrates may cause sublethal effects in developing G. geographica. In Pennsylvania, Nagle et al. (2018) reported that $29 \%$ of females nesting at a former industrial site along the Juanita River had carapace abnormalities, with older females displaying the highest frequency of abnormalities. The causes of the abnormalities are unclear but may have been related to historical soil or water contamination, or to the excessive temperatures that nests located in black coal tailings experienced at that site. Hatchlings did not display abnormalities, suggesting that whatever caused the deformities at that site had since been alleviated.

Conservation Measures Taken. - It is now illegal to capture any turtle in Wisconsin before 15 July and after 30 November, such that the turtles are protected until the end of the nesting season and can not be taken when hibernating. In the Upper Mississippi River Wildlife Refuge in Pool 8 in Vernon Co., Wisconsin, the USFWS has been building islands for duck and turtle nesting habitat since 2011 (Vogt, pers. obs.). The islands were built to be permanent with a rip-rap base covered with dredge spoil sand. They are shaped like crab claws, which offers a physical structure to capture sand and silt to continue the building process, and a shallow backwater area as a nursery for hatchling turtles and ducklings. The oldest islands were only a year old when map and softshell turtles were already observed nesting, indicating that turtles do not always return to nest on the beach where they hatched (Vogt, unpubl.data). They were planning to build
50 such islands; 14 had already been built by 2012 . Nesting islands away from the mainland will diminish depredation of the nesting females, their eggs and their hatchlings from mammalian predators. The Department of Natural Resources banned the biological supply house industry in Wisconsin from wholescale collecting of all animals for sale, particularly turtles, in 2004. They also limited the use of the number of traps commercial turtle trappers could use. Maintenance of basking logs near the nesting island is necessary, since $G$. geographica is very wary and does not generally bask on logs or branches connected to the shoreline of the river.

Graptemys geographica was assessed as Least Concern for the IUCN Red List in 1996, but not listed since LC species were not being listed at that time. It was re-assessed as Least Concern in 2010 and listed on the IUCN Red List (van Dijk 2011). All Graptemys spp. are listed by the USA on CITES Appendix III. The US Endangered Species Act lists the species as Special Concern, and the Canada Species at Risk Act also lists it as Special Concern. It occurs in many protected areas across its range.

Conservation Measures Proposed. - Gill netting for fish should be prohibited within $2 \mathrm{~km}$ of nesting beaches. Recent studies have developed and tested strategies such as exclusion devices and escape modifications to reduce and avoid freshwater turtle mortality in hoop nets (Larocque et al. 2012b,c; Cairns et al. 2013, 2017). Given the low resiliency of turtle populations to adult mortality, such strategies should be adopted by all freshwater fisheries that risk drowning turtles. Exclusion devices and net modifications may not be practical with gill nets, and buffer zones between nets and important turtle habitats such as nesting and hibernating sites should be established. In areas of high boat activity, it is advisable to adopt measures to reduce boat traffic near basking and nesting aggregations to reduce disturbances, injuries, and mortality. Drift fences associated with under-road culverts may be a viable option to reduce road mortality, in some areas; G. geographica was reported to use culverts installed to reduce road mortality, but the success of this mitigation strategy depends on the design and integrity of the fencing system used to direct animals to the culverts (Markle et al.2017). Activities that affect native mollusk populations (e.g., siltation, pollution) should be more strongly regulated.

Captive Husbandry. - Graptemys geographica is less hardy in captivity than False maps or Ouachita maps. They appear to need a higher protein diet and are more susceptible to bacterial and fungal infections (Vogt, unpubl. data). As with all species of Graptemys, basking sites are essential and sunlight or artificial sources of UV are paramount to the success of rearing this species in captivity. Longevity in captivity exceeds 20 years; an adult captured in the wild lived for 18 years in the Brookfield Zoo (Slavens and Slavens 2000). 
Current Research. - Research programs on $G$. geographica are ongoing in Northern Indiana (since 1979), Pennsylvania (since 1999), and Ontario (since 2003).

Acknowledgments. - Iverson's work with this species was funded by the Joseph Moore Museum of Natural History and the Biology Department at Earlham College. We thank Mathieu Ouellette for the use of his photos.

\section{LITERATURE CITED}

AdLER,L.L. 1968.Turtles from archeological sites in the Great Lakes region. Michigan Archeologist 14:147-163.

Agassiz, L. 1857. Contributions to the Natural History of the United States of America. First Monograph. Vol. I. Part I. Essay on Classification.Part II. North American Testudinata. Boston: Little, Brown and Co., Vol. I, pp. 1-452.

Anderson, R.V., Gutierrez, M.L., and Romano, M. 2002. Turtle habitat use in a reach of the upper Mississippi River. Journal of Freshwater Biology 17:171-177.

AsHLEY,E.P. AND RoBINSON,J.T.1996. Road mortality of amphibians, reptiles and other wildlife on the Long Point Causeway, Lake Erie, Ontario. Canadian Field-Naturalist 110:403-412.

BaKer, P.J., Costanzo, J.P., Iverson, J.B., AND LeE, R.E., JR. 2003. Adaptations to terrestrial overwintering of hatchling Northern Map Turtles, Graptemys geographica. Journal of Comparative Physiology, B. Biochemical Systemic and Environmental Physiology 173:643-651.

Baker, P.J., Iverson, J.B., Lee, R.E., JR., ANd Costanzo, J.P. 2010. Winter severity and phenology of spring emergence from the nest in freshwater turtles. Naturwissenschaften 97:607-615.

BaKer, P.J., Costanzo, J.P., Iverson, J.B., AND Lee, R.E., JR. 2013. Seasonality and interspecific and intraspecific asynchrony in emergence from the nest by hatchling freshwater turtles. Canadian Journal of Zoology 91:451-461.

Banger, N., Blouin-Demers, G., Bulté, G., And Lougheed, S.C. 2013. More sires may enhance offspring fitness in Northern Map Turtles (Graptemys geographica). Canadian Journal of Zoology 91:581-588.

BARRETT BEEHLER,K.M.2007.An investigation of the abundance and key habitat parameters of the Northern Map Turtle (Graptemys geographica) in an eastern Ontario bay. M.S. Thesis, University of Waterloo, Canada.

Ben-Ezra,E.,Bulté,G., And Blouin-Demers, G. 2008.Are locomotor performances coadapted to preferred basking temperature in the Northern Map Turtle (Graptemys geographica)? Journal of Herpetology 42:322-331.

BennetT, A.M. And LitzGus, J.D. 2014. Injury rates of freshwater turtles on a recreational waterway in Ontario, Canada. Journal of Herpetology 48:262-266.

Bennett, A.M., Keevil, M., And Litzgus, J.D. 2009. Demographic differences among populations of Northern Map Turtles (Graptemys geographica) in intact and fragmented sites.Canadian Journal of Zoology 87:1147-1157.

Bennett, A.M., KeEVIL, M., And Litzgus, J.D. 2010. Spatial ecology and population genetics of Northern Map Turtles (Graptemys geographica) in fragmented and continuous habitats in Canada. Chelonian Conservation and Biology 9:185-195.

Bluett, R.D., Louis, W.E., Newhouse, D.A., Handel, C.J., JR., AND KUBE,J.H.2013.Assemblages in an altered river in central Illinois, USA: implications for conservation. Transactions of the Illinois
State Academy of Science 106:47-53.

BodIE, J.R. 2001. Stream and riparian management of freshwater turtles. Journal of Environmental Management 62:443-455.

BROOKs,D.R. 1979. New records for amphibian and reptile trematodes. Proceedings of the Helminthological Society of Washington 46:286-289.

Browne, C.L. And Hecnar, S.J. 2005. Capture success of Northern Map Turtles (Graptemys geographica) and other turtle species in basking vs. baited hoop traps. Herpetological Review 36:145-147.

Browne, C.L. AND Hecnar, S.J. 2007. Species loss and shifting population structure of freshwater turtles despite habitat protection. Biological Conservation 138:421-429.

Buhlmann, K.A., Akre, T.S., Iverson, J.B., Karapatakis, D., MitTermeir, R.A., Georges,A., Rhodin, A.G.J., van DiJK, P.P., AND GibBons, J.W. 2009. A global analysis of tortoise and freshwater turtle distributions with identification of priority conservation areas. Chelonian Conservation and Biology 8:116-149.

Bull, J.J. And Vogt, R.C. 1979. Temperature controlled sex determination in turtles. Science 206:1186-1188.

Bull, J.J., Vogt, R.C., AND McCoy, C.J. 1982. Sex determining temperatures in turtles: a geographic comparison. Evolution $36: 326-332$.

Bulté, G. and Blouin-Demers, G. 2008. Northern Map Turtles (Graptemys geographica) derive energy from the pelagic pathway through predation on Zebra Mussels (Dreissena polymorpha). Freshwater Biology 53:497-508.

Bulté, G. and Blouin-Demers, G. 2009. Does sexual bimaturation affect the cost of growth and the operational sex ratioin an extremely size-dimorphic reptile? Ecoscience 16:175-182.

Bulté, G. and Blouin-Demers, G. 2010a. Implications of extreme sexual size dimorphism for thermoregulation in a freshwater turtle. Oecologia (Berlin) 162:313-322.

Bulté, G. and Blouin-Demers, G. 2010b. Estimating the energetic significance of basking behaviour in a temperate-zone turtle. Ecoscience 17:387-393.

Bulté,G.,CARrière, M.-A., AND Blouin-Demers, G. 2010. Impact of recreational power boating on two populations of Northern Map Turtles (Graptemys geographica). Aquatic Conservation: Marine and Freshwater Ecosystems 20:31-38.

Bulté, G., Gravel, M.A., and Blouin-Demers, G. 2008 a. Intersexual niche divergence in Northern Map Turtles (Graptemys geographica): the roles of diet and habitat. Canadian Journal of Zoology 86:1235-1243.

Bulté, G., Irschick, D.J., and Blouin-Demers, G. 2008b. The reproductive role hypothesis explains trophic morphology dimorphism in the Northern Map Turtle. Functional Ecology 22:824-830.

Bulté, G., Germain, R.R., O’Connor, C.M., and Blouin-Demers, G. 2013. Sexual dichromatism in the Northern Map Turtle, Graptemys geographica. Chelonian Conservation and Biology 12:187-192.

Bulté, G., Chlebak, R.J., Dawson, J.W., and Blouin-Demers, G. 2018. Studying mate choice in the wild using 3D printed decoys and action cameras: a case of study of male choice in the Northern Map Turtle. Animal Behaviour 138:141-143.

Cable, R.M. And Hopp, H.W. 1954. Acanthocephalan parasites of the genus Neoechinorhynchus in North American turtles with descriptions of two new species. Journal of the Tennessee Academy of Science 40:674-680.

CAHn, A.R. 1937. The Turtles of Illinois. Illinois Biological Monograph 16(1-2):1-218.

Cairns, N.A., Stoot, L.J., Blouin-Demers, G., and Cooke, S.J. 2013. Refinement of bycatch reduction devices to exclude freshwater turtles from commercial fishing nets. Endangered 
Species Research 22:251-261.

Cairns, N.A., Stoot, L.J., Blouin-Demers, G., and Cooke, S.J. 2017. Using behavioral observations to develop escape devices for freshwater turtles entrapped in fishing nets. Journal of Fish and Wildlife Management 8:4-14.

CARriÈre, M.-A. 2007. Movement patterns and habitat selection of common map turtles (Graptemys geographica) in St. Lawrence Islands National Park, Ontario, Canada. M.S. Thesis, University of Ottawa, Canada.

CArrière, M.-A. AND Blouin-Demers, G. 2010. Habitat selection at multiple spatial scales in Northern Map Turtles (Graptemys geographica). Canadian Journal of Zoology 88:846-854.

Carrière, M.-A., Bulté, G., and Blouin-Demers, G. 2006. Movement patterns and population ecology of the Common Map Turtle (Graptemys geographica) and Stinkpot Turtle (Sternotherus odoratus) in Lake Opinicon (Rideau Canal National Historic Site) and at St. Lawrence Islands National Park. Unpublished Report to Parks Canada, 16 pp.

Carrière, M.-A., Bulté, G., and Blouin-Demers, G. 2009. Spatial ecology of Northern Map Turtles (Graptemys geographica) in a lotic and a lentic habitat. Journal of Herpetology 43:597-604.

Catrysse, J., Emily, S., Choquette, J., Leifso, A.E., and Davy, C.M. 2015. Mass mortality of Northern Map Turtles (Graptemys geographica). Canadian Field Naturalist 129:80-83.

Choquette, J.D. And Valliant, L. 2016. Road mortality of reptiles and other wildlife at the Ojibway Prairie complex and greater park ecosystem in Southern Ontario. Canadian Field Naturalist 130:64-75.

Christiansen, J.L. 2001. Non-native amphibians and reptiles in Iowa. Journal of the Iowa Academy of Science 108:210-211.

Cochran, P.A. 1987. Life history notes. Graptemys geographica (map turtle). Adult mortality. Herpetological Review 18:37.

Colt, L.C., Jr., SAumure, R.A., AND B ASKinger, S. 1995. First record of the algal genus Basicladia (Chlorophyta, Cladophorales) in Canada. Canadian Field Naturalist 109:454-455.

Congdon,J.D.,Tinkle,D.W., And Rosen, P.C. 1983.Egg components and utilization during development in aquatic turtles. Copeia 1983:264-268.

Conner,A.C.,BrookeA.D.,AND Ryan,T.J.2005.Descriptive ecology of a turtle assemblage in an urban landscape. American Midland Naturalist 153:428-435.

Costanzo,J.P.,BAKER,P.J., AND SWIHART, R.E.,JR.2006.Physiological responses to freezing in hatchlings of freeze-tolerant and-intolerant turtles. Journal of Comparative Physiology, B. Biochemical Systemic and Environmental Physiology 176:697-707.

Crocker, C.E., Graham, T.E., Ultsch, G.R., and Jackson, D.C. 2000. Physiology of common map turtles (Graptemys geographica) hibernating in the Lamoille River, Vermont. Journal of Experimental Zoology 286:143-148.

Daigle, C., Desrosiers, A., And Bonin, J. 1994. Distribution and abundance of Common Map Turtles, Graptemys geographica, in the Ottawa River, Québec. Canadian Field Naturalist 108:84-86.

DeCantanzaro, R. and ChOW-Fraser, P. 2010. Relationship of road density and marsh condition to turtle assemblage characteristics in the Laurentian Great Lakes. Journal of Great Lakes Research 36:357-365.

DeGiusti, D.L. And Batten, P.J. 1951. Notes on Haemoproteus metchinikovi in turtles from Wisconsin, Michigan, and Louisiana. Journal of Parasitology 37(supplement): 12.

Dinkelacker, S.A., Costanzo, J.P., And Lee, R.E. 2005. Anoxia tolerance and freeze tolerance in hatchling turtles. Journal of Comparative Physiology, B. Biochemical Systemic and Environmental Physiology 175:209-217.
DonnerWright, D.M., BozeK, M.A., Probst, J.R., And Anderson, E.M. 1999. Response of turtle assemblage to environmental gradients in the St. Croix River in Minnesota and Wisconsin, U.S.A. Canadian Journal of Zoology 77:989-1000.

Dreslik, M.J., KuHNS, A.R., AND PhILLIPS, C.A. 2005. Structure and composition of a southern Illinois freshwater turtle assemblage. Northeastern Naturalist 12:173-186.

Duchak, T. AND Holzapfel, C. 2011. The relative abundances of native and non-native emydid turtles across an urban to rural habitat gradient in central New Jersey. Bulletin of the New Jersey Academy of Science 56:23-28.

Edgren, R.A., Edgren, M.K., And Tiffany, L.H. 1953. Some North American turtles and their epizoophytic algae. Ecology 34:733-740.

FAY,L.P. 1988.Late WiconsinanAppalachian herpetofaunas: Relative stability in the midst of change. Annals of the Carnegie Museum 57:189-220.

FisHER, F.M., JR. 1960. On acanthocephalans of turtles, with the description of Neoechinorynchus emyditoides $\mathrm{n}$. sp. Journal of Parasitology 46:257-266.

FlAHERTY, N. 1982. Home range, movement, and habitat selection in a population of map turtle, Graptemys geographica (Le Sueur), in the northern part of its range. Canadian Journal of Zoology 58:2210-2219.

Flaherty, N. And Bider, J.R. 1984. Physical structures and the social factor as determinant of habitat use by Graptemys geographica in southwestern Quebec. American Midland Naturalist 11:259-266.

Freedberg, S. And Myers, E.M. 2012. Cytonuclear equilibrium following interspecific introgression in a turtle lacking sex chromosomes. Biological Journal of the Linnean Society 106:405-417.

FuseliER, L. AND EDDS, D. 1994. Habitat partitioning among three sympatric species of map turtles, genus Graptemys. Journal of Herpetology 28:154-158.

GARMAN, S. 1890. The differences between the geographic turtles (Malacoclemmys geographicus and M. lesueuri). Bulletin of the Essex Institute 12:1-14.

Geller, G.A. 2012. Notes on the nest predation dynamics of Graptemys at two Wisconsin sites using trail camera monitoring. Chelonian Conservation and Biology 11:197-205.

GiBBons, J.W. 2013. A long-term perspective of delayed emergence (aka overwintering) in hatchling turtles: some they do and some they don't, and some you just can't tell. Journal of Herpetology 47:203-214.

GibBons, J.W. And Nelson, D.H. 1978. The evolutionary significance of delayed emergence from the nest by hatchling turtles. Evolution 32:297-303.

Gislason, D., Reid, K., And Oldenburg, K. 2010. Assessment and mitigation of the effects of commercial fishing activities on aquatic species at risk in Long Point Bay, Toronto. Species at Risk Research Fund for Ontario, Report SARF151.

Goodpaster, W.W. AND Hoffmeister, D.H. 1952. Notes on the mammals of Western Tennessee. Journal of Mammalogy 33:362-371.

Gooley, A.C, Atanton, J.C., Bartkus, C.J., And Pauley, T.K. 2011. The distribution of aquatic turtles along the Ohio, Great Kanawha, and Little Kanawha Rivers, West Virginia, with emphasis on Graptemys ouachitensis and G. geographica. Ohio Biological Survey Notes 3:21-28.

Gordon, D.M. And MacCulloch, R.D. 1980. An investigation of the ecology of the map turtle, Graptemys geographica (LeSueur) in the northern part of its range. Canadian Journal of Zoology 
58:2210-2219.

Graham, T.E. AND Graham, A.A. 1992. Metabolism and behavior of wintering common map turtles, Graptemys geographica, in Vermont. Canadian Field-Naturalist 106:517-519.

Graham, T.E., Saumure, R.A., AND Ericson, B. 1997. Map Turtle winter leech loads. Journal of Parasitology 83:1185-1186.

Graham, T.E., Graham, C.B., Crocker, C.E., and Ultsch, G.R. 2000. Dispersal from and fidelity to a hibernaculum in a northern Vermont population of Common Map Turtles, Graptemys geographica. Canadian Field-Naturalist 114:405-408.

GRAY,J.E.1830.ASynopsis of the Species of theClass Reptilia.In: Griffith E. and Pidgeon, E. The Class Reptilia arranged by the Baron Cuvier, with specific descriptions.In: Griffith,E.(Ed.). The Animal Kingdom Arranged in Conformity with its Organization, by the Baron Cuvier, with Additional Descriptions of all the Species Hitherto Named, and of many not before Noticed. Vol. 9. Reptilia. Supplement. London: Whittaker, Treacher, and Co., $110 \mathrm{pp}$.

Gritters, S.A. and Mauldin, L.M. 1994. Four years of turtle collections on navigation pool 13 of the Upper Mississippi River. Unpublished report LTRMP 94-S010 of the Iowa Department of Natural Ressources Bellevue, Iowa for the National Biological Survey, Environmental Management Technical Center, Onalaska, Wisconsin.

Guilday, J.E., Hamilton, H.W., Anderson, E., And Parmalee, P.W. 1978. The Baker Bluff Cave deposit, Tennessee, and the Late Pleistocene faunal gradient. Bulletin of the Carnegie Museum of Natural History 11:1-67.

HARRAH, E.C. 1922. North American monostomes primarily for fresh water hosts. Illinois Biological Mongraphs 7:1-107.

Hartzell, S.M. 2017. Glyptemys insculpta (Wood Turtle) and Graptemys geographica (Northern Map Turtle). Interspecific basking. Herpetological Review 48:622.

Hernandez-Divers, S.J., Hensel, P., Gladden, J., Hernandez-Divers, S.M., Buhlmann, K.A., Hagen, C., Sanchez, S., Latimer, K.S., ARD, M., AND CAMus, A.C. 2009. Investigation of shell disease in map turtles (Graptemys spp.). Journal of Wildlife Diseases 45:637-652.

Hibbard, C.W., Zakrewski, R.J., Eshelman, R.E., Edmund, G., GRIGGS, C.D., AND GRIGGS, C. 1978. Mammals from the Kanapolis local fauna, Pleistocene (Yarmouth) of Ellsworth County, Kansas. Contributions for the Museum of Paleontology, University of Michigan 25:11-44.

Higgins, S.N. AND VANDER Zanden, M.J. 2010.What a difference a species makes: a meta-analysis of dreissenid mussel impacts on freshwater ecosystems. Ecological Monographs 80:179-196.

HolBROOK, J.E. 1836. North American Herpetology; or a Description of the Reptiles Inhabiting the United States. Ed. 1, Vol. 1. Philadelphia: Dobson and Son, 55 pp.

Holman, J.A. 1969. The Pleistocene amphibians and reptiles of Texas. Publications of the Museum, Michigan State University, Biological Series 4:161-192.

Holman, J.A. 1972. Herpetofauna of the Kanapolis local fauna (Pleistocene: Yarmouth) of Kansas. Michigan Academician 5:87-98.

Hopp, W.B. 1946. Notes on the life history of Neochinorhynchus emydis (Leidy), an acanthocephalan parasite of turtles.Proceedings of the Indiana Academy of Science 55:183.

Hopp, W.B. 1954. Studies on the morphology and life cycle of Neochinorhynchus emydis (Leidy), an acanthocephalan parasite of the map turtle. Journal of Parasitology 40:284-299.

Horsfall, H.W. 1935. Observations on the life history of Macravestibulum obtusicaudum Mackin, 1930 (Trematoda: Pronocephalidae). Proceedings of the Helminthological Society of Washington 2:78-79.

Hsû,D.Y.M. 1937.Life history and morphology of Macravestibulum eversum sp. nov. (Pronocephalidae, Trematoda). Transactions of the American Microscopical Society 56:478-504.

Hughes, R.C., Higginbotham, J.W., and Clary, J.W. 1942. The trematodes of reptiles, partI: systematic section.American Midland Naturalist 27:109-134.

IVERSON, J.B. 1988. Growth in the common map turtle, Graptemys geographica. Transactions of the Kansas Academy of Sciences 91:153-157.

Iverson, J.B. 1992. A Revised Checklist with Distribution Maps of the Turtles of the World. Richmond, IN: Privately printed, $363 \mathrm{pp}$.

Iverson, J.B., ERnst, C.H., GotTe, S.W., AND Lovich, J.E. 1989. The validity of Chinemys megalocephala (Testudines, Batagurinae). Copeia 1989:494-498.

Jackson, D.C., Taylor, S.E., Asare, V., Villarnovo, D., Gall, J., AND ReESE, S.A. 2007. Comparative shell buffering properties correlate with anoxia tolerance in freshwater turtles. American Journal of Physiology - Regulation, Integration, and Comparative Physiology 292:R1008-15.

JaIn-Schlaepfer, S.M.R., Blouin-Demers, G., CoOKe S.J., and Bulté, G. 2016. Do boating and basking mix? The effect of basking disturbances by motorboats on the body temperature and on the energy budget of the Northern Map Turtle. Aquatic Conservation: Marine and Freshwater Ecosystems 27:547-558.

JanZen, F.J.,PAukstis, G.L., ANd BRodie, E.D., III. 1992. Observations on basking behavior of hatchling turtles in the wild. Journal of Herpetology 26:217-219.

Jenkins, J.T. And Semken, H.A. 1972. Faunal analysis of the Lane Enclosure, Allamakee County, Iowa. Proceedings of the Iowa Academy of Science 78:76-78.

Johnson, P.D., Bogan, A.E., Brown, K.M., Burkhead, N.M., Cordeiro, J.R., Garner, J.T., Hartfield, P.D., Lepitzki, D.A.W., Mackie, G.L., Pip, E., Tarpley, T.A., Tiemann, J.S., Whelan, N.V., AND STRONG, E.E. 2013. Conservation status of freshwater gastropods of Canada and the United States. Fisheries 38:247-282.

KILLEBREW, F.C. 1977. Mitotic chromosomes of turtles. IV. The Emydidae. Texas Journal of Science 29:245-253.

LAGLER, K.F. 1943. Food habits and economic relations of the turtles of Michigan with special reference to fish management. American Midland Naturalist 29:257-312.

LAMB, T. AND OSENTOSKI, M.F. 1997. On the paraphyly of Malaclemys: a molecular genetic assessment. Journal of Herpetology 31:258265.

Lamb, T., Lydeard, C., Walker, R.B., and Gibbons, J.W. 1994. Molecular systematics of map turtles (Graptemys): a comparison of mitochondrial restriction site versus sequence data. Systematic Biology 43:543-559.

Larocque, S.M., Colotelo, A.H., Cooke, S.J., Blouin-Demers, G., Haxton, T., AND SMOKorowsKi, K.E. 2012a. Seasonal patterns in bycatch composition and mortality associated with a freshwater hoop net fishery. Animal Conservation 15:53-60.

Larocque, S.M., Cooke, S.J., and Blouin-Demers, G. 2012b. Mitigating bycatch of freshwater turtles in passively-fished fyke nets through the use of exclusion and escape modifications. Fisheries Research 125-126:149-155.

Larocque, S.M., Cooke, S.J., and Blouin-Demers, G. 2012c. A breath of fresh air: avoiding anoxia and mortality of freshwater turtles in fyke nets by the use of floats. Aquatic Conservation: Freshwater and Marine Ecosystems 22:198-205.

LESUEUR, C.A. 1817. An account of an American species of tortoise not noticed in the systems. Journal of the Academy of Natural Sciences of Philadelphia 1:86-88. 
Limsuwan, C. AND DunN, M.C. 1978. A survey of helminth parasites from turtles in Rutherford County, Tennessee. Journal of the Tennessee Academy of Science 53:111-114.

LindEMAN, P.V. 1997. A comparative spotting-scope study of the distribution and relative abundance of river cooters (Pseudemys concinna) in western Kentucky and southern Mississippi. Chelonian Conservation and Biology 2:378-383.

LINDEMAN, P.V. 1998. Of deadwood and map turtles (Graptemys): an analysis of species status for five species in three river drainages using replicated spotting-scope counts of basking turtles. Linnaeus Fund research report. Chelonian Conservation and Biology 3:137-141.

LINDEMAN,P.V. 1999. Surveys of basking map turtles Graptemys sp.in three river drainages and the importance of deadwood abundance. Biological Conservation 88:33-42.

Lindeman, P.V. 2000. Evolution of the relative width of the head and alveolar surfaces in map turtles (Testudines: Emydidae: Graptemys). Biological Journal of the Linnean Society 69:549-576.

Lindeman, P.V. 2006. Zebra and Quagga Mussels (Dreissena spp.) and other prey of a Lake Erie population of common map turtles (Emydidae: Graptemys geographica). Copeia 2006:268-273.

Lindeman, P.V. 2013. The Map Turtle and Sawback Atlas: Ecology, Evolution, Distribution, and Conservation. Norman, OK: University of Oklahoma Press, $460 \mathrm{pp}$.

Lindeman, P.V. 2015. Surveys of basking turtles in the rivers of northeastern Oklahoma, with emphasis on Graptemys geographica (Common Map Turtle). Proceedings of the Oklahoma Academy of Science 94:1-9.

LINDEMAN,P.V.2017.Graptemys geographica (common map turtle). Epibiont. Herpetological Review 48:177-178.

LindEMAn, P.V. AND SHARKEY, M.J. 2001. Comparative analyses of functional relationships in the evolution of trophic morphology in the map turtles (Emydidae: Graptemys). Herpetologica 57:313-318.

Lovich, J.E. And GibBons, J.W. 1990. Age at maturity influences adult sex ratio in the turtle Malaclemys. Oikos 59:126-134.

Maginniss, L.A., Ekelund, S.A., And Ultsch, G.R. 2004. Blood oxygen transport in common map turtles during simulated hibernation. Physiological and Biochemical Zoology 77:232-241.

Markle, C.E., Gillingwater, S.D., Levick, R., and Chow-Fraser, P. 2017. The true cost of partial fencing: evaluating strategies to reduce reptile road mortality. Wildlife Society Bulletin 41: 342-350.

Mazak, E.J., Macisaac, H.J., Servos, M.R., and Hesslein, R. 1997. Influence of feeding habits on organochlorine contaminant accumulation in waterfowl on the Great Lakes. Ecological Applications 7:1133-1143.

McCoy, C.J. And Vogt, R.C. 1990. Graptemys geographica. Catalogue of American Amphibians and Reptiles 484.1-4.

Mercer, J.L., Fox, M.G., And Metcalfe, C.D. 1999. Changes in benthos and three littoral zone fishes in a shallow, eutrophic Ontario lake following the invasion of the Zebra Mussel (Dreissena polymorpha). Lake and Reservoir Management 15:310-323.

Midwood, J.D., Cairns, N.A., Stoot, L.J., Cooke, S.J., and BlouinDemers, G. 2015. Bycatch mortality can cause extirpation in four freshwater turtle species. Aquatic Conservation: Marine and Freshwater Ecosystems 25:71-80.

Mitchell, S.M., Muehlbauer, L.K., and Freedberg, S. 2016. Nuclear introgression without mitochondrial introgression in two turtle species exhibiting sex-specific trophic differentiation. Ecology and Evolution 6:3280-3288.

Moll, D. 1976. A review of supposed insect catching by basking
Graptemys geographica.Transactions of the Illinois State Academy Sciences 69:302-303.

Molv, D. 1977. Ecological investigations of turtles in a polluted ecosystem: the central Illinois river and adjacent flood plain lakes. $\mathrm{Ph} . \mathrm{D}$. Dissertation, Illinois State University, Normal.

NAgLe, R.D. And Congdon, J.D. 2016. Reproductive ecology of Graptemys geographica of the Juniata River in central Pennsylvania, with recommendations for conservation. Herpetological Conservation and Biology 11:232-243.

Nagle, R.D., Lutz, C.L., ANd Pyle, A.L. 2004. Overwintering in the nest by hatchling map turtles (Graptemys geographica). Canadian Journal of Zoology 82:1211-1218.

Nagle, R.D., Rowe, C.L., Grant, C.J., Sebastian, E.R., and Martin, B.E. 2018. Abnormal shell shapes in Northern Map Turtles of the Juniata River, Pennsylvania, USA. Journal of Herpetology 52:59-66.

Newman, H.H. 1906. The habits of certain tortoises. Journal of Comparative Neurology and Psychology 16:126-152.

Nickerson, M.A. ANd PITt, A.L. 2012. Historical turtle population decline and community changes in an Ozark river. Bulletin of the Florida Museum of Natural History 51:257-267.

Nickerson, M.A., Mays, C.E., TohulKa, M.D., and Barton, H.E. 1984. Changing chelonian populations in a spring-fed Ozark river. (Abstract). ASIH, SSAR, and HL Joint Meeting, p.165.

NutTing, W.L. AND GRAHAM, T.E. 1993. Preferred body temperatures in five Nearctic freshwater turtles: a preliminary study. Comparative Biochemistry, Physiology A. Comparative Physiology 104:243246.

Ossiboff, R.J., Newton, A.L., Seimon, T.A., Moore, R.P., And McAloose, D. 2015. Emydid herpesvirus 1 infection in northern map turtles (Graptemys geographica) and painted turtles (Chrysemys picta). Journal of Veterinary Diagnostic Investigation 27:92-395.

Ouellette, M. And Cardille, J.A. 2011. The complex linear home range estimator: representing the home range of river turtles moving in multiple channels. Chelonian Conservation and Biology 10:259-265.

PAPPAS, M.J., CONGDON, J.D, AND BRECKE, B.J. 2017. Orientation of five species of hatchling river turtles dispersing from experimental nests. Chelonian Conservation and Biology 16: 3-11.

PenN, G.H. 1950. Utilization of crayfishes by cold-blooded vertebrates in the eastern United States. American Midland Naturalist 44:643-658.

Peterman, W.E. And Ryan, T.J. 2009. Basking behavior of emydid turtles (Chrysemys picta, Graptemys geographica, and Trachemys scripta) in an urban landscape. Northeastern Naturalist 16:629-636.

Pitt, A.L. AND Nickerson, M.A. 2012. Reassessment of the turtle community in the North Fork of the White River, Ozark County, Missouri. Copeia 2012:367-374.

PITT,A.L.ANDNICKERSON,M.A.2013.Potential recovery of adeclined turtle population diminished by a community shift towards more generalist species. Amphibia-Reptilia 34:193-200.

PitT, A.L. AND Nickerson, M.A. 2014. Description and comparison of turtle assemblages and populations located within a spring-fed river. Herpetological Conservation and Biology 9:475-483.

Pluto, T.G. And Bellis, E.D. 1986. Habitat utilization by the turtle Graptemys geographica, along a river. Journal of Herpetology 20:22-21.

Pluto, T.G. AND Bellis, E.D. 1988. Seasonal annual movements of riverine map turtles, Graptemys geographica. Journal of Herpetology 22:152-158.

Pluto, T.G. And Rothernbacher, H. 1976. Eimeria juniataensis sp. n. (Protozoa: Eimeriidae) from the map turtle, Graptemys 
geographica, in Pennsylvania.Journal of Parasitology 62:207-208.

Powell, R., Conant, R., And Collins, J.T. 2016. Peterson Field Guide to Reptiles and Amphibians of Eastern and Central North America. Fourth Edition. Boston, Houghton Mifflin Harcourt.

Poly, W.J. 1999. Herpetofauna of the Little South Fork Basin (Cumberland River drainage), Wayne and McCreary Counties, Kentucky. Ohio Journal of Science 99:26-29.

RAUSCH, R. 1946. New host records for Microphallus ovatus Osborn, 1919. Journal of Parasitology 32:93-94.

RAUSCH, R. 1947. Observations on some helminthes parasitic in Ohio turtles. American Midland Naturalist 38:434-442.

Reese, S.A., Crocker, C.E., CARwILE, M.E., JaCKson, D.C., AND UltsCH, G.R. 2001. The physiology of hibernation in common map turtles (Graptemys geographica). Comparative Biochemistry and Physiology 130A:331-340.

ReEse, S.A., Ultsch, G.R., and Jackson, D.C. 2004. Lactate accumulation, glycogen depletion, and shell composition of hatchling turtles during simulated aquatic hibernation. Journal of Experimental Biology 207:2889-2895.

RESHKE, N. 2009. Factors affecting leech parasitism on four turtle species in St.Lawrence Islands National Park. B.S.Honors Thesis, University of Ottawa, Ontario, Canada.

RichARDS-DiMITRIE,T.M. 2011. Spatial ecology and diet of Maryland endangered Northern Map Turtles (Graptemys geographica) in an altered river system: implications for conservation and management. M.S. Thesis, Towson University, Maryland.

Richards-Dimitrie, T.M.,Gresens, S.E., Smith, S.A., And Seigel, R.A. 2013. Diet of Northern Map Turtles (Graptemys geographica): sexual differences and potential impacts of an altered river system. Copeia 2013:477-484.

RizKalla, C.E. AND SwiHart, R.K. 2006. Community structure and differential responses of aquatic turtles to agriculturally induced habitat fragmentation. Landscape Ecology 21:1361-1375.

Rowe, J.W., Miller, B .J., Stuart, M.A., Snyder, C., Tucker, J.K., Clark,D.L.,WitTLE,L.W., AND LAMER,J.T.2014. Substrate colorinduced melanization in eight turtle species from four chelonian groups. Zoology 117:245-252.

RyAn, K.M. AND LindEMAn, P.V.2007. Reproductive allometry in the common map turtle, Graptemys geographica.American Midland Naturalist 158:49-59.

RYAN, T.J. AND LAMBERT, A. 2005. Prevalence and colonization of Placobdella on two species of freshwater turtles (Graptemys geographica and Sternotherus odoratus). Journal of Herpetology 39:284-287.

Ryan, T.J., Conner, C.A., Douthitt, B.A., Sterrett, S.C., And SAlsbury, C.M. 2008. Movement and habitat use of two aquatic turtles (Graptemys geographica and Trachemys scripta) in an urban landscape. Urban Ecosystems 11:213-225.

SAUMURE, R.A. And Livingston, P.J. 1994. Graptemys geographica (Common Map Turtle). Parasites. Herpetological Review 25:121.

SAUMURE, R.A., WALDE,A.D., AND WhEELER,T.A.2006.Nonpredatory fly larvae (Delia platura: Anthomyiidae) in a nest of a Northern Map Turtle (Graptemys geographica). Chelonian Conservation and Biology 5:274-275.

SERrouya, R.A., Ricciardi,A., AND Whoriskey, F.G. 1995. Predation on Zebra Mussels (Dreissena polymorpha) by captive reared Map Turtles (Graptemys geographica). Canadian Journal of Zoology 73:2238-2243.

Slaughter, B.H., Crook, W.W., Jr., Harris, R.K., Allen, D.C., AND SEIFEN, M. 1962. The Hill-Schuler local faunas of the Upper Trinity River, Dallas and Denton counties, Texas. University of Texas Bureau of Economic Geology, Report of Investigations No. 48,75 pp.
Slavens, F. and Slavens, K. 2000. Reptiles and amphibians in captivity, breeding - longevity and inventory current January 1, 1999. Seattle, WA: Slaveware, $400 \mathrm{pp}$.

Smith, G.R. And Iverson, J.B. 2004. Diel activity patterns of the turtle assemblage of a northern Indiana lake. American Midland Naturalist 152:156-164.

Smith, G.R., Iverson, J.B., And Rettig, J.E. 2006. Changes in a turtle community from a northern Indiana lake: a long-term study. Journal of Herpetology 40:180-185.

SPECK, D.W. 2015. The ontogenetic effects on the shell strength of turtles. B.S. Honors Thesis, Butler University, Indianapolis, Indiana.

Steen, D.A., Aresco, M.J., Beilke, S.G., Compton, B.W., Condon, E.P., Dodd, C.K., JR., Forrester, H., Gibbons, J.W., Greene, J.L., Johnson, G.,Langen, T.A., Oldham, M.J., Oxier, D.N., Saumure, R.A., Schueler, F.W., Sleeman, J.M., Smith, L.L., Tucker, J.K., AND GIBBS, J.P. 2006. Relative vulnerability of female turtles to road mortality. Animal Conservation 9:269-273.

Steen, D.A., Gibbs, J.P., Buhlmann, K.A., Carr, J.L., Compton, B.W., Congdon, J.D., Doody, J.S., Godwin, J.C., Holcomb, K.L., JACKSON, D.R., JANZEN, F.J., JoHNSON, G., JoNES, M.T., LAMER, J.T., Langen, T.A.,Plummer,M.V.,Rowe,J.W.,SAumure,R.A.,Tucker, J.K., AND WILSON, D.S. 2012. Terrestrial habitat requirements of nesting freshwater turtles. Biological Conservation 150:121-128.

STEPHENS, P.R. AND WIENS, J.J. 2003. Ecological diversification and phylogeny of emydid turtles. Biological Journal of the Linnean Society 79:577-610.

StePhens, P.R. And Wiens, J.J. 2004. Convergence, divergence, and homogenization in the ecological structure of emydid turtle communities: the effects of phylogeny and dispersal. American Naturalist 164:244-254.

Stoot, L., Cairns, N., Blouin-Demers, G., and Cooke, S.J. 2013. Physiological disturbances and behavioural impairment associated with the incidental capture of freshwater turtles in a commercial fyke-net fishery. Endangered Species Research 21:13-23.

Storey, K.B. and Storey, J.M. 2017. Molecular physiology of freeze tolerance. Physiological Reviews 97:623-665.

Stovall, J.W. and McAnulty, W.N. 1950. The vertebrate fauna and geologic age of Trinity River terraces in Henderson County, Texas. American Midland Naturalist 44:211-250.

StunKard, H.W. 1917. Studies on North American Polystomidae, Aspidogastridae and Paramphistomidae. Illinois Biological Monographs 3:1-115.

StunKard, H.W. 1921. Notes on North American blood flukes. American Museum Novitates 12:1-5.

StunKARD, H.W. 1922. Two new genera of North American blood flukes. American Museum Novitates 39:1-8.

Surface, H.A. 1908. First report on the economic features of the turtles of Pennsylvania. Zoological Bulletin of the Division of Zoology of the Pennsylvania Department of Agriculture 6:107-196.

Temple-Miller, K.G. 2008. Use of radiotelemetry and GIS to distinguish habitat use between Graptemys ouachitensis and $G$. geographica in the Scioto River. M.S. Thesis, Ohio University, Athens, Ohio.

Thomson, R.C., Spinks, P.Q., And Shaffer, H.B. 2018. Molecular phylogeny and divergence of the map turtles (Emydidae: Graptemys). Molecular Phylogenetics and Evolution 121:61-70.

Tran, S.L., Moorhead, D.L., And McKenna, K.C. 2007. Habitat selection by native turtles in a Lake Erie wetland, USA. American Midland Naturalist 158:16-28.

TTWG [Turtle TAXONOMY Working Group] [RHodin, A.G.J., IVERson, J.B., Bour, R. Fritz, U., Georges, A., Shaffer, H.B., AND VAN Disk, P.P.]. 2017. Turtles of the World: Annotated Checklist 
and Atlas of Taxonomy, Synonymy, Distribution, and Conservation Status (8th Ed.). In: Rhodin, A.G.J., Iverson, J.B., van Dijk, P.P., Saumure, R.A., Buhlmann, K.A., Pritchard, P.C.H., and Mittermeier, R.A. (Eds.). Conservation Biology of Freshwater Turtles and Tortoises: A Compilation Project of the IUCN/SSC Tortoise and Freshwater Turtle Specialist Group. Chelonian Research Monographs 7:1-292.

TUCKER, J.K. 2004. Turtle trapping at Swan Lake and Gilbert Lake: results for 2004. INHS Center for Aquatic Ecology, 2 pp.

Ultsch, G.R. 2006. The ecology of overwintering among turtles: where turtles overwinter and its consequences. Biological Reviews 81:339-367.

Ultsch, G.R., Graham,T.E., AND CROCKER,C.E.2000.An aggregation of overwintering leopard frogs, Rana pipiens, and common map turtles, Graptemys geographica in northern Vermont. Canadian Field Naturalist 114:314-315.

Van Cleave, H.J. 1913. The genus Neorhynchus in North America. Zoologischer Anzeiger 43:177-190.

VAN DIJK, P.P. 2011. Graptemys geographica (errata version published in 2016). The IUCN Red List of Threatened Species 2011: e.T165598A97418743. http://dx.doi.org/10.2305/IUCN. UK.2011-1.RLTS.T165598A6065540.en.

Vandewalle, T.J. And Christiansen, J.L. 1996. A relationship between river modification and species richness of freshwater turtles in Iowa. Journal of Iowa Academy of Science 103:1-8.

VoGT, R.C. 1978. Systematics and ecology of the false map turtle complex Graptemys pseudogeographica. Ph.D. Dissertation, University of Wisconsin, Madison.

VoGT, R.C. 1979. Cleaning/feeding symbiosis between grackles (Quiscalus: Icteridae) and map turtles (Graptemys: Emydidae). Auk 96:608-609.

Vogt, R.C. 1980a. New methods for trapping aquatic turtles. Copeia 1980:368-371.

VoGT,R.C.1980b.Natural history of Graptemys pseudogeographica and Graptemys ouachitensis in Wisconsin. Tulane Studies in Zoology 22:17-48.

Vogt, R.C. 1981a. Natural History of Amphibians and Reptiles in Wisconsin. Milwaukee: Milwaukee Public Museum, 265 pp.

Vogt, R.C. 1981b. Food partitioning among three species of Graptemys. American Midland Naturalist 105:102-111.

Vogt, R.C. 1981c. Predation of turtle eggs (Graptemys: Emydidae) by fly larvae (Sarcophagidae: Diptera). Copeia 1981:457-459.

VoGt, R.C. 1993. Systematics of the false map turtles (Graptemys pseudogeographica complex: Reptilia, Testudines, Emydidae). Annals of the Carnegie Museum 62:1-46.

VoGT, R.C. 2012. Detecting and capturing turtles in freshwater habitats. In: Dodd, C.K., Jr. (Ed.). Reptile Biodiversity: Standard Methods for Inventory and Monitoring. Berkeley: University of
California Press, pp. 335-337.

Vogt, R.C. ANd Bull, J.J. 1984. Ecology of hatchling sex ratio in map turtles. Ecology 65:582-587.

WACHA, R.S. AND Christiansen, J.L. 1976. Coccidian parasites from Iowa turtles: systematics and prevalence. Journal of Protozoology 23:57-63.

WADE, S.E. AND GIFFORD, C.E. 1965. A preliminary study of the turtle population of a northern Indiana lake. Proceedings of the Indiana Academy of Science 74:371-374.

WARD, J.M. AND RICCIARDI, A. 2007. Impacts of Dreissena invasions on benthic macroinvertebrate communities: a meta-analysis. Diversity and Distributions 13:155-165.

WEBER,A.S. AND LAYZER, J.B. 2011.A comparison of turtle sampling methods in a small lake in Standing Stone State Park, Overton County, Tennessee. Journal of Tennessee Academy of Science 86:454-52.

White, D. AND Moll, D. 1991. Clutch size and annual reproductive potential of the turtle Graptemys geographica in a Missouri stream. Journal of Herpetology 25:493-494.

White, D. And Moll, D. 1992. Restricted diet of the Common Map Turtle Graptemys geographica in a Missouri stream. Southwestern Naturalist 37:317-318.

Whitear,A.K., Wang, X., CAtling, P., McLennan, D.C., and Davy, C.M. 2017. The scent of a hatchling: intra-species variation in the use of chemosensory cues by neonate freshwaterturtles. Biological Journal of the Linnean Society 120:179-188.

Wiens, J.J., KuCZYNSKI, C.A., AND STEPHENS, P.R. 2010. Discordant mitochondrial and nuclear gene phylogenies in emydid turtles: implications for speciation and conservation. Biological Journal of the Linnean Society 99:445-461.

Wieten, A.C., Cooper, M.J.,PARKer, A.D., AND UZARski, D.G. 2012. Great Lakes coastal wetland habitat use by seven turtle species: influences of wetland type, vegetation, and abiotic conditions. Wetlands Ecology and Management 20:47-58.

Woo, P.T.K. 1969. Trypanosomes in amphibians and reptiles in southern Ontario. Canadian Journal of Zoology 47:1139-1151.

\section{Citation Format for this Account:}

Vogt, R.C., Bulté, G., And Iverson, J.B. 2018. Graptemys geographica (LeSueur 1817) - Northern Map Turtle, Common Map Turtle. In: Rhodin, A.G.J., Iverson, J.B., van Dijk, P.P., Buhlmann,K.A.,Pritchard,P.C.H., and Mittermeier, R.A.(Eds.). Conservation Biology of Freshwater Turtles and Tortoises: A Compilation Project of the IUCN/SSC Tortoise and Freshwater Turtle Specialist Group. Chelonian Research Monographs 5(11):104.1-18. doi: 10.3854/crm.5.104.geographica.v1.2018; www.iucn-tftsg.org/cbftt/. 